\title{
Surgery of the autonomic nervous system
}

Guy R. McCutcheon

University of Nebraska Medical Center

This manuscript is historical in nature and may not reflect current medical research and practice. Search PubMed for current research.

Follow this and additional works at: https://digitalcommons.unmc.edu/mdtheses

Part of the Medical Education Commons

\section{Recommended Citation}

McCutcheon, Guy R., "Surgery of the autonomic nervous system" (1931). MD Theses. 163.

https://digitalcommons.unmc.edu/mdtheses/163

This Thesis is brought to you for free and open access by the Special Collections at DigitalCommons@UNMC. It has been accepted for inclusion in MD Theses by an authorized administrator of DigitalCommons@UNMC. For more information, please contact digitalcommons@unmc.edu. 
SUHION THESTS

$$
\text { 20IL 28, } 1937 .
$$

\section{SURCBRY}

of the

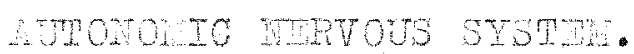

Wir. of IDBR. SOLIDGE Of YEUTGMT.
GUY a meOUTGEOT. 


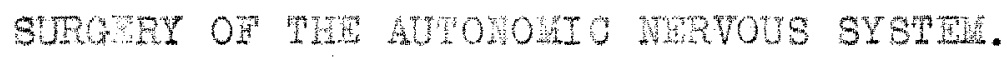

The greet rolme of anetonice and physiologicel reeerroh that res been directed towere the autonomic nervous syeten durine the pest fer years has been responible ior an alnost ecual srount of ettengted olinios apolicetion in the form of surgexy.

The results of these atsenpts heve indeed been variable;

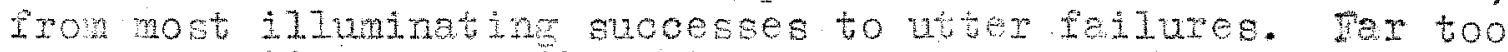
ment opexations upon the automato mervous syten heve been undertaken on e purely emplicel besis. mperies beve often

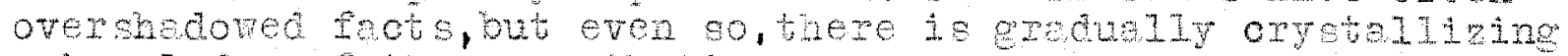
a knowledge of the smpethetio nerrous system thet in certeir to remove this branch of suregry from the category of surgionl curiosities to a postion mome ofintsely indosted, retionsl prooedures.

iny dupose in selecting co techrion a subject does not Include desine to even point out, much lese discuss, al of the ontrovereier and contradidone thet heve been so detrimentel to the prostesg of this new ield, nor do I intend to speculate, but menely to powt out come of the thines thet are mow, and to tndecte the striking pesuth that follow a proper applicetion of these Eats.

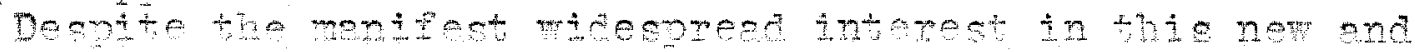

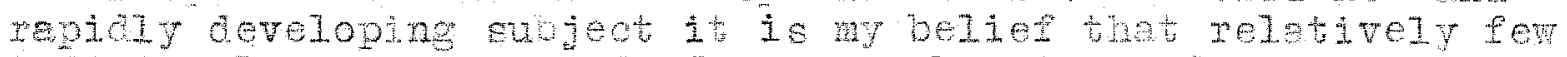
individude are poesesed oz a compehenetue underetending of it. Such an wheretencine is not eesily obtatned and bis efior hes not been without aiseppointinent but it ia hoped thet it wil meteel the pesent statue of surgery of the autonowio nervous eysuem.

The phrese "Autononic Nervous Syetent is employed in a eenerel rey, as Penson, Kuntz end Adson heve used it, to designate thet functional divion of the sympethetio nervous eqsetat mich euplies the elands, heart ene suooth muscle with their efferent innervation, this inolues the orenioseorel os well es the thoracioo-lunbar dtweton of Ghe synpethetio nervous systen - an explanetion of the Ietter two divisione vili be undertaken later.

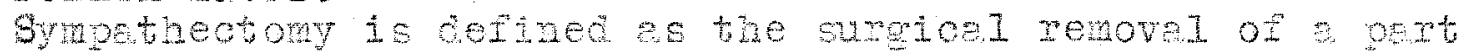

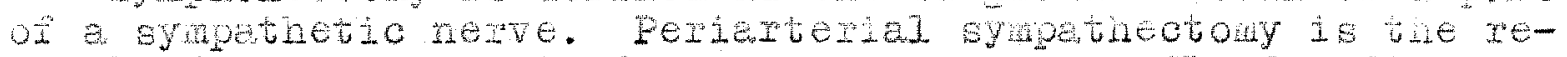
notel of we adventitis from an entery evopoedy dendine

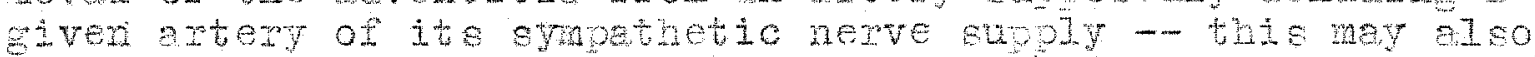

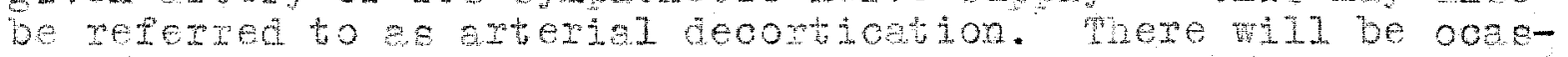
exon to use these terme ryeguentig.

sympthetio tenglioncotomy, ramidectomy, and trum reseo-

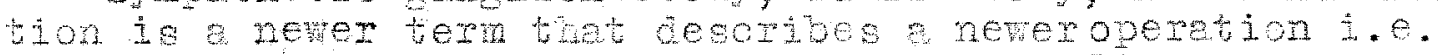
extimpetion of one or more sympthetio sangla, ceverance of all rani communicentes and resection of thet portion of

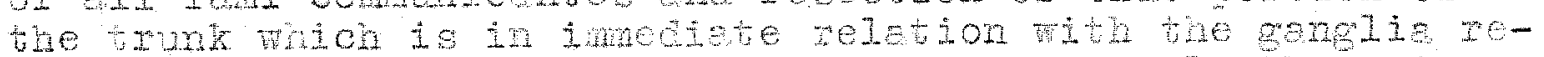

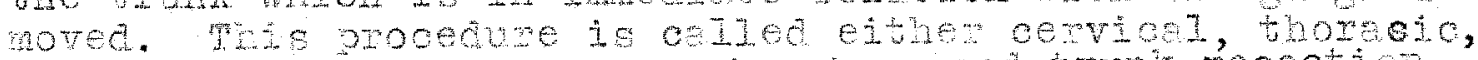

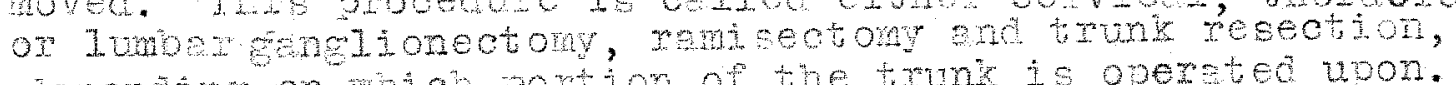
dependine on thol portion of the trun is opereted upon. 
Whe andory of the sypethetio nervoue opstem is entinely too compliceter for a lenethy presentetion in this papet but

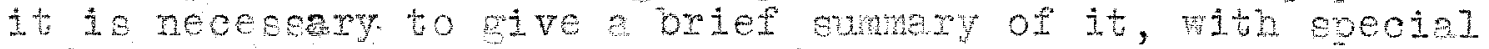
reference to centar important leote.

In generel the sympthetio nemoue syetem is an egregetion oi ganglis, plemses, rand nerve ijors whoh eupply the elands, heart, and smooth made. Whetw moet abunent dietribution is in the oranid vedlt and neok, the thotecto and abdomnel cevities 2 . and 2.

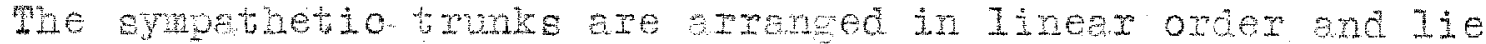
alons the ventrolateral aspers of whe vertebral column. They extend tron the bese of the chul to the cocoys. Eech symothetho trunk is mede up of a series of twenty-one ow twenty-two

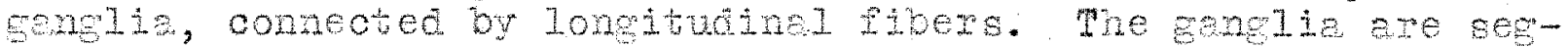

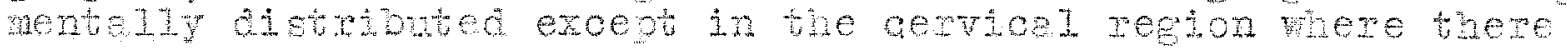
are only thee viz. the supenior cervica symosthetio ganglia--

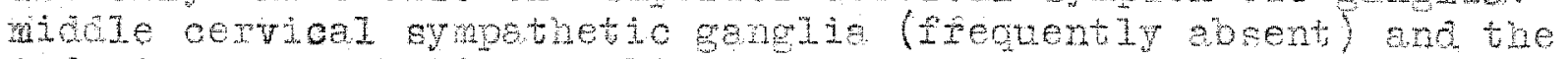
inferioz symethetio genelis.

The gensite are comeotid wh the spinel nerves thm

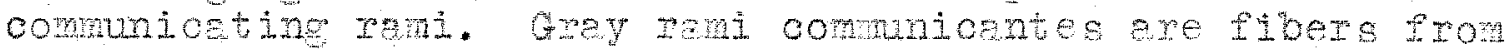
the aympethetio trund which connect the eqmpethetios with every spinel nerve on the exne ejce only. whte ram are only civen

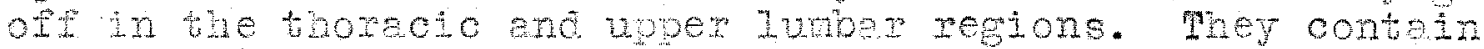

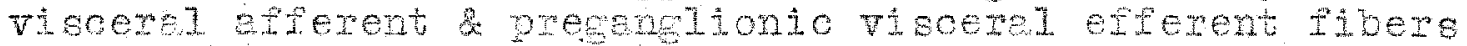
whoh co trom the centrel nervous eveten to the shonthetio

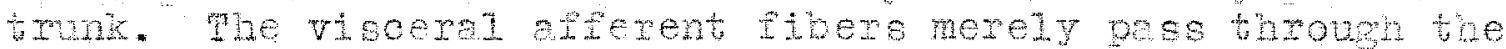

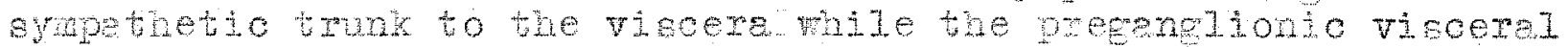

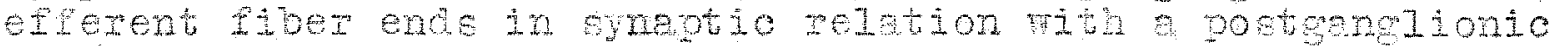
neuron in the ajupthetio genelis. Thise ram contain only

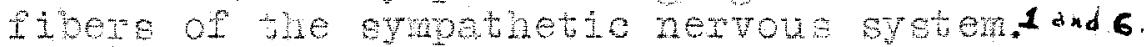

pere are three etreane of pregnelionio iners whan leeve twe cerebrospinal axis, the orexal brem, the thoractoo lumber

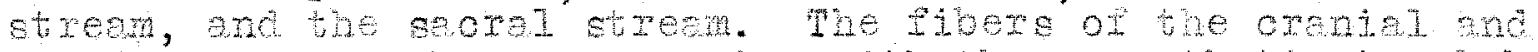
cacrel etreams meke no connexion with fhe symptretio trun but sun arectiy to the symothetio neve plexues, but bine fibere

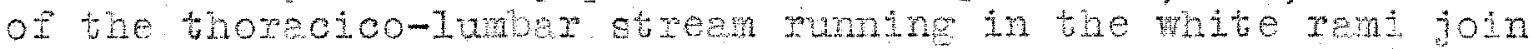
the symathetic trunk and terminate in the ernelis of the trunk. the crental and saoral streens end in the teminal ganglia.1. It is obrious that the distribution of the crentel and sacral groups j. similer while thet of the thorecto and lumoem streane is elso eniler but distinoty diferent then the oraniobacra. It hes also been noted thet the zeeponse of the orental end

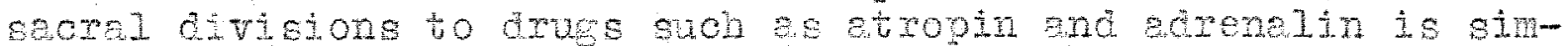

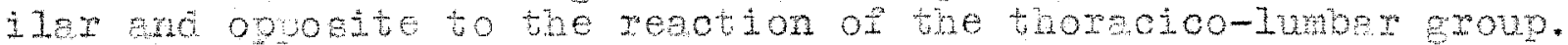
therefore the crenial and secrel divisione heve been rouped together sne caled the porasmpethetio steten what the thoreci0o-lumbar group is temed the aympthetio newrovs erstem.

The functionel reletionehip of these tro eysteme is vexy important. Phis peper wil desi elmoet entirely with the symp-thetio difieton of the autononio nervoue aystem.

One other fect is esential to a fundanentel concept of the

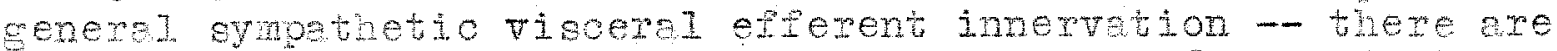

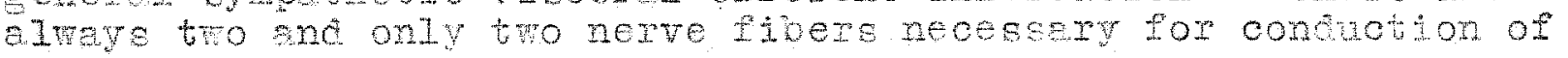
an impulse iron the oentrel nervous eystem to e eland or enooth muscle. They are preganglionio end a postenglio fiber. 1 . 
wor or the meteriel thet is to rol ow is directiy depencant upon the synpethesio nerve supply to erteries so thet this wil be desorioed an some cetail.

Recent experimentation has broven beyond all doubt thet axteries of the otremities receive their evipethetio innervetion frow ediecent eptral nerves th thtervale throughout the leneth of their course.2. Wo laree lonejtudinel. punte of tibere extendine irour the periextextal plexuses along the course of the sutery oen be emonetreted es was formexu belieted to exist. 2and 29

It is asemed though not proven thet the eympthetio nerve

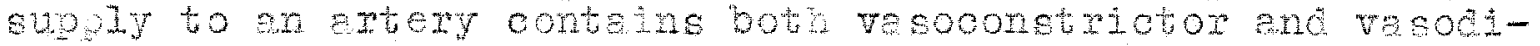
latator fibers. The aorte, vertebrel end cerotid arivertes are suppied by piexuses. Arteries of the extremities are supolied

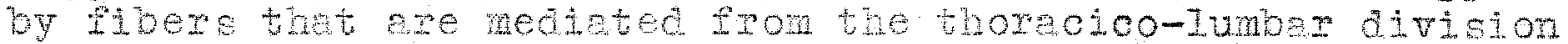
of the symothetio tunk. Whese tibere are natributed by the corresondine peripheral rexve as a vesomotor component and gives

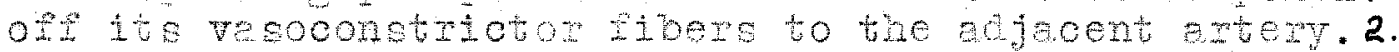

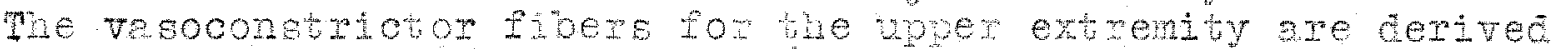

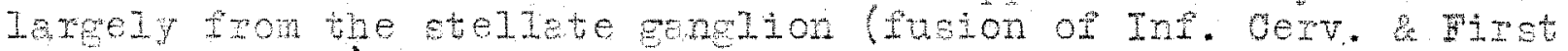

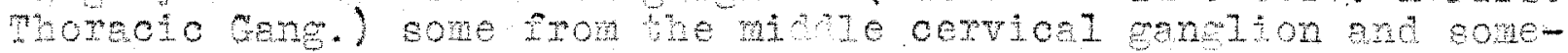
tines there axe branches from the breonid plezus end the second thorecic genelion. The lower extrenty id lereay euputed by

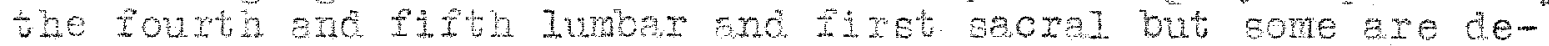

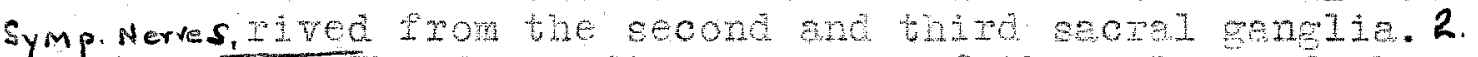

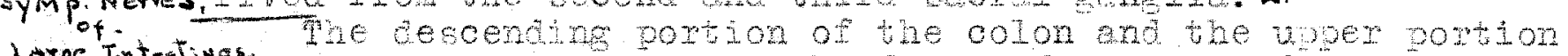

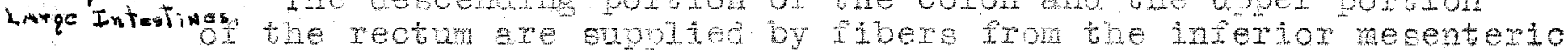
plexus whoh is the cervetive of be artio olexus and therefore

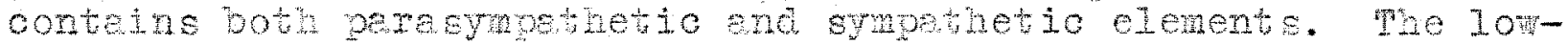
er pert of the rectum is eupliec by joese derived from the whte remi of the secone, thine and founth lumber nemesphose fibers are ultimetely distibuted to the oirowan miscles by rey of the hyogastic enc pelvic plemuses.3. Whe symothetio tibers ceuse dilatetion of the ciroular muses of the integtine mile the perasymathetio nerves canse contration. The imoctence of these Peote will becone evident leser.3.

the nerve suply to the hest wes a mettex or oonaiderabe arement unil tecenty and ell men are not yet agreed as to de-

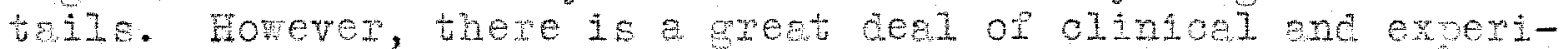
wentel evidence of the exstence of acolemetor cardieo nerves

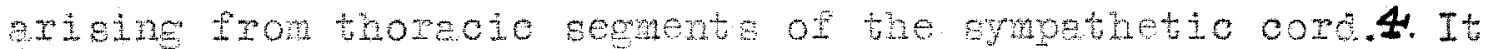
was romely thoteht the ell orrateo acelerator or empethetio

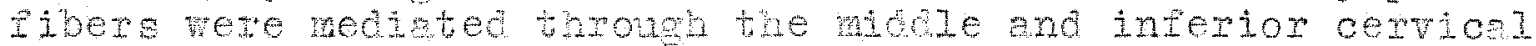
symothetio genelie. In a recent study by munt on fetuses and edult odevers acceleretor fibere to the heert rere treced Ixom the second and third thorecic sympethetic senglid in all cases and oonetine a brench from be fourh thorato genelia

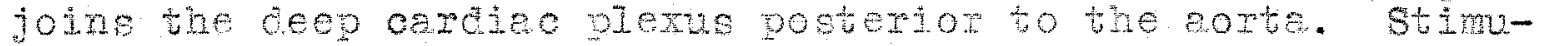
Wettion of any of any of these fibers results in soceleretion of the heart rate so it to obvious tat reflex cardac acoeleration will not be boliched even atter cervical ermothetio gangion-

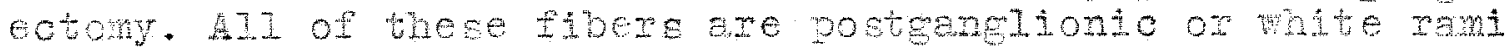
arteng eron ronglie of the sympthetio trunk. Whe oorfecoondIng pregnelionid fuens ono components of the uppes thomeic 
nertes dom to end induding the fith. these sibese rovia the enmivs of Vievseus to the inferior cervicel genelion. 5 . the sentory or encerent nerve bupply of the hemt is not well underebood. Where are sersory pibers for the heert which reach the syoethetio nervous system through the white ram of the voper thee thorecio gangla and the vegue on the left side.6. However, reworal of the lest superior cervioal ganglion does abolich the pein realex. phe pan of angine ta peterred to the outhneous distibution of the firet three thorecie epinal merve of the left side and therefore these nerves nust also contain sone aferent components.6. In man pain in the heart and eortio arol is modieted via the aidele and inferior oariac nerres, throush the lower cervical and upper thoracic portions of the eympethetio trunk - then along the upper thoredio white remi to the corregpondine pinel neves and then to uhe splnaI $\cot c^{3} .6$.

The and ony of the symothetic innervation of viscera is also important becauee acoording to bhe weckenzie theory of pein the peinful atimlus is initisted in the sympthetio neve supply of a given oxgan, it is nediated to the sympethetio trunk and

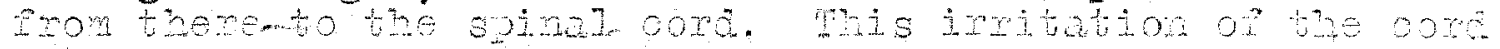
leses to e conecious sensetion which is referred by the brein to the exterior segment of the body innerveted by the eptnel nerve of the comesponding imrteted portion of the cord. These facte as wil be pointed out later will becone of great signifionce in the development of sugery of the atonomic nexrous bystren.

The physioly of the butonomic nerwous systen reneins a complexty especieliy the reletion of aleturbed sympethetic iunction to disese but correlation wh never rnatomiogl fincinge snd studite upon operete cases promises to shed mon light on the subject.

In generet be symethetic division of the cutonomid nerrous syoten is exoitatory while the parasymethetio syetem is

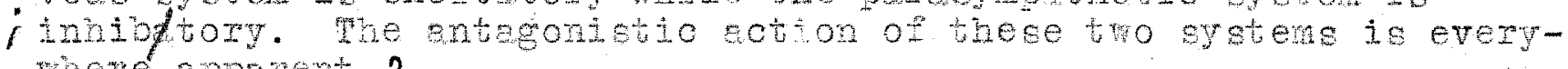
there a operent. 2.

The intomet organs are supplied with bot aypethetic and paresyathetio fibers 00 that they receive impulseg from videly eeverated centers in the contrat nervoue system.

The action of the sympatnetio enc perasymethetio eystems may be compred to the action of cerebroeplnel nerres es tlexors

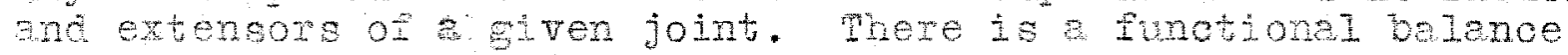
menteined and a trend towate symethetio overectivity has been temed srmpetheticotonia while hyperectivity of the peraetnpathetio gystem has cone to be mom oliniogly as vegetona.2.

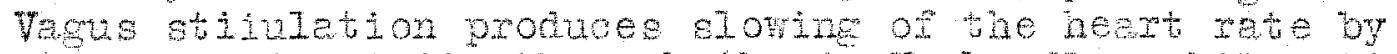
decreesug conductivity thouph the A. V. buale, mate stimulation of the armpthetios scolerates the heart rete. Their action is peversed in the thostines where the peregymethetic

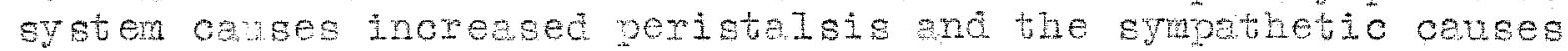
slowng. The paresymathetio cystem inhibis the cecretion of 
svest glande, ovuses congtrition of the pupils thrournt preganghonic inbere of the oculomotor herve and neurone in the

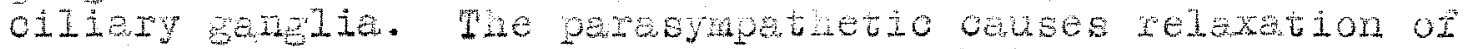

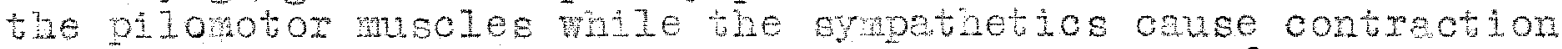
of thee mases and stimulates the greet glends. 2.

The functon of the sympthetio and parasypethetio divisione of the autonomic nexwote syeten a regercs the innervetion

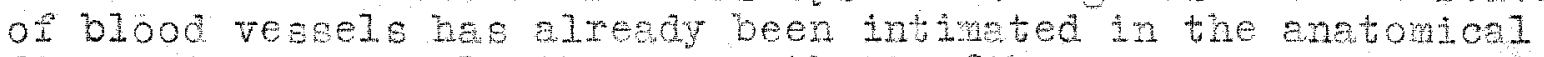

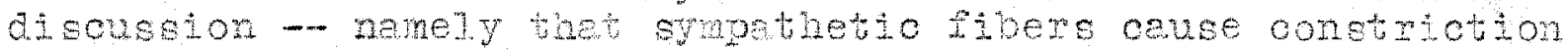
of blood vesels and perestmpsthetio gtimuletion cevees distetion. AII arbexies and veine with few exoetions do acturly constrict in response to symethetio etinulation while there are no knom pathuas for the flow of cremiel or seorn fibers to the ressels of the extremities or sonftic portion of the trun. 2 . studies after uniletere lumbar sympatheotomy on doge have proven thet the temperature of the limb on the penatud atoe tras

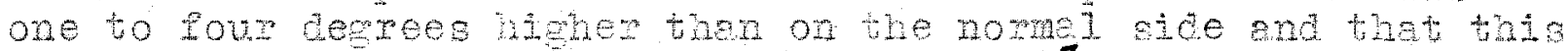
elevation persibed for bi least two weeks. These Pincings

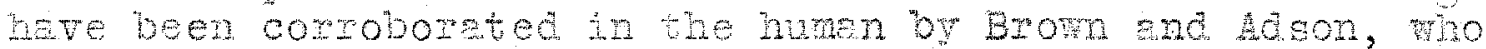
etete thot resodintetion of ewtentes of the peet and lower pert or the lese is rerrod as mensured by themometrio methods whe that the vesodilatetion he pereifted as lone as brae reate atter opersion.5. Otner stwites prove thet eymptidetio

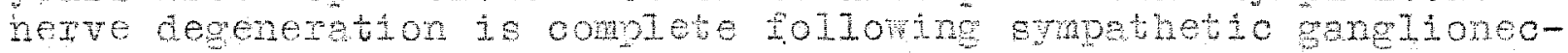
tomy so thet vesoduletation ousht to be perment folloring operetion ne tndeed such seens to be the cese.8. Bollowing experinentaI sympanetio genglionectom, ramisecwory and trunk rececton

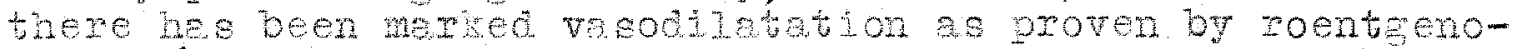
grene. 14. There is undoubtedy cone vasodiletetion following periatiental smpetheotom? but the hes been chom by $x-x e y$ to be of evenescent character lasting only about ton minutes. Brom anc hoson state thet the phyeiolopios chenges ocoung

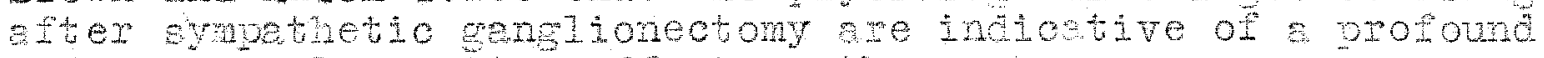

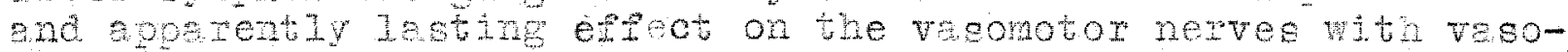

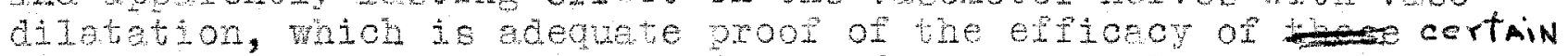

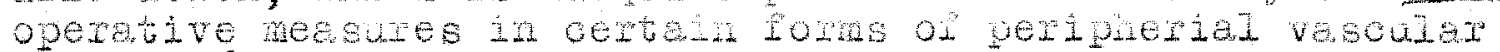

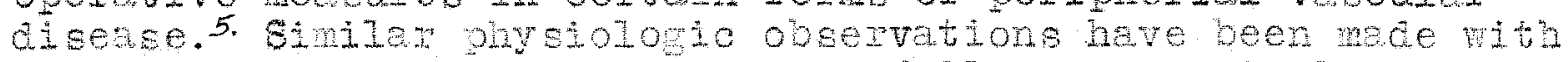
tererence to the upoer extremties following cervich and thometo gymothetic anglionectomy and the re heve demowatrated the seme reneral efiects.5.

A Iose of the sweating ane planotor reflexes iN corresponeine areas was a constant observation. Foljoning exolston of the Pixet and secono thoracto ompothetio sanglie there res no disburbanoe of cordieo acolemeton but a bi-leterel Horner

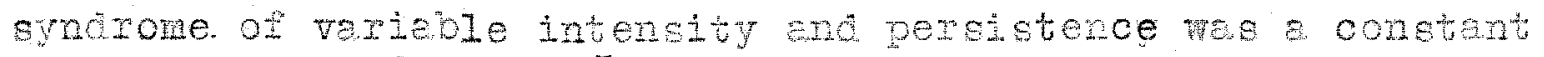
post operetive findine. 5 .

Liwb developent, oseous, muscular and cutaneons was per-

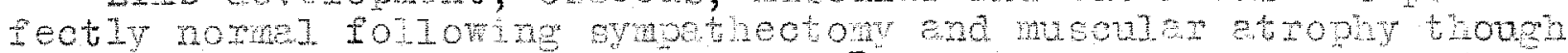
ocasionel1y obeerved 1 transiont.?

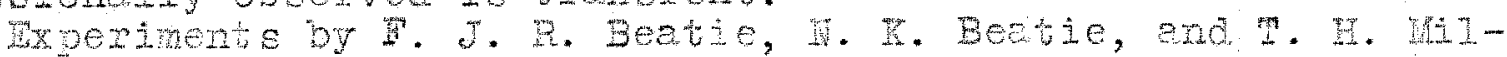

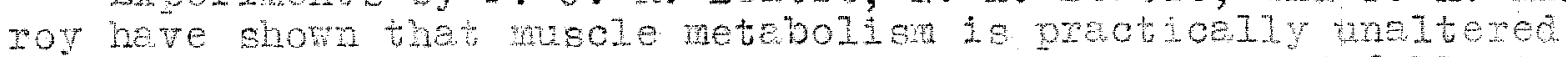

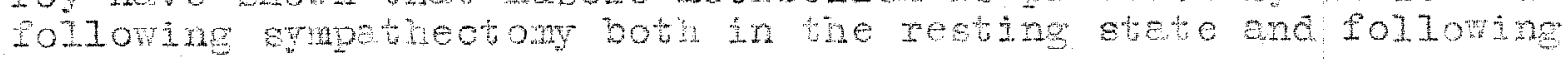
cretsotse. 10 .

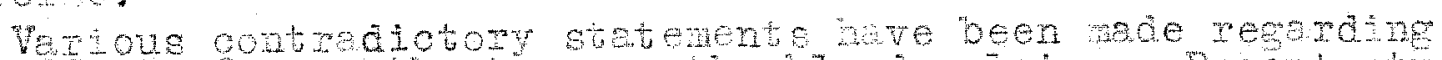

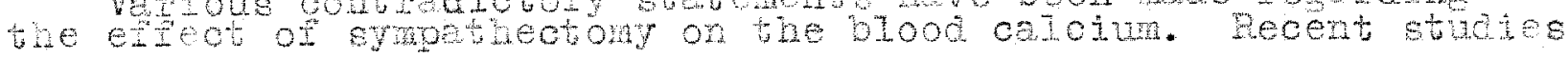


by Jose Larelos heve defritely proven thet the oblotum level rerane precticelly constant wethex he syopthetio nervous eretenis removed en toto on in pert. $\mu$.

Surgery of be eutonomid nerrous syben 15 older then is genereliy euppoec. Interect in the subject hes been inter-

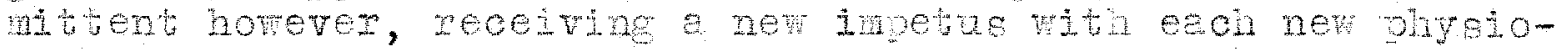
Losical om enetomicel atsoovery.

Jebouley of Lyons, Frence wes inspied by the work of the physologiet, olende Bemerd, who denonstreted the trophic influenoe of nerver and the mechang of vasonotom oontrol caliber. of bloot veseele by the etmpethetic nervous syetrem.

In 1889 he attemoted to apply the abore knomedee and perforaed decorticetion of the fenoral artery for cure of ulcer of the fopt. He observed sone of the oiroulatory phenonene seen todey followne this operetion with some improvement in bhe

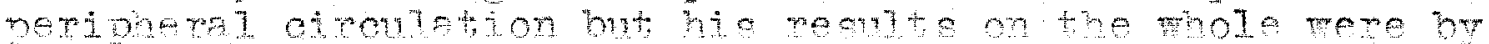
no neene striktne, his eqforta were coldy receired, and the mork felt into obsourity.

sinoe artertal decortication or pertertexial eympethectony was ine tingt operation to be pertomed it is convenient to Pollow is developnent up bo the presert time.

In 1001 heser recomended bentre the nerve plews around the femorel artery in ceses ol intermitent oleudiodtion. 2 mis is the single ethenpt to be found in the literature nntil the Greet wax.

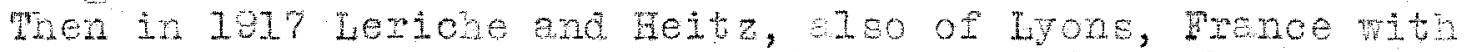

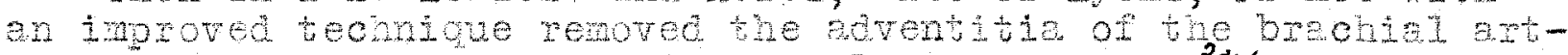

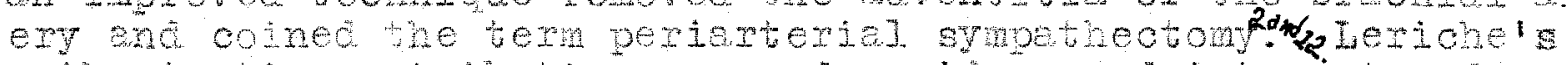
enthusiastio contrabtions cused 6 mitespead interest ant the prockente as cescribed by him he been periomed extensive$1 y$ twrourhout the United strtes ano murope ever since. 22.

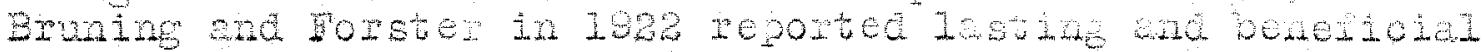
resulte in selerodeme and heynaude. 2.

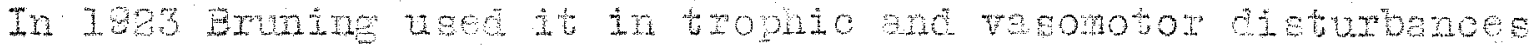
in begining eagrene.

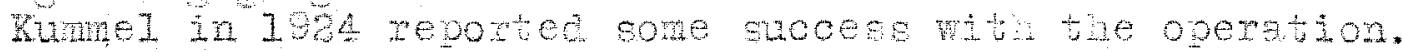

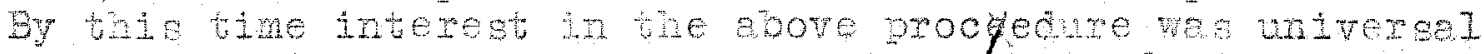

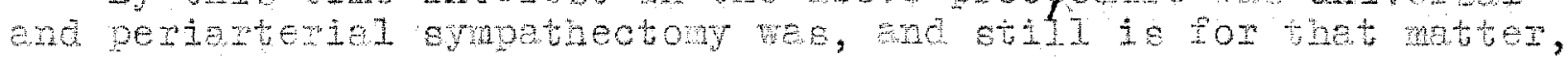

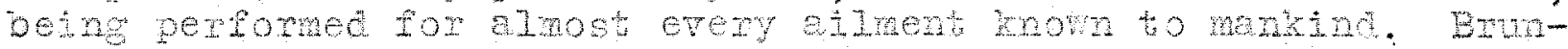

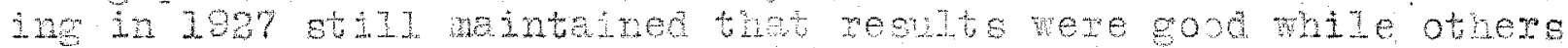

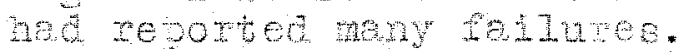

Leziche te the outstatine erponent of this fom of operetion at the present ine; he essumes thet the resoconctriotor fibers ior outeneons blook vessels of the extrentties heve a coure like thet taken by the fibers for the solanomio vescels - thet is, join the gorts or othex Ispe orterieg in the bhorex and abdonen and we theix wat to the pexiphery in the pexiarterial plexuser.6. But I have shom thet such is not the oese

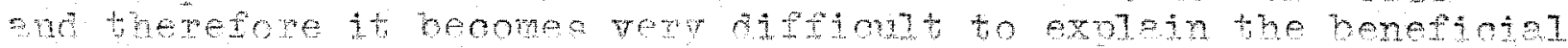

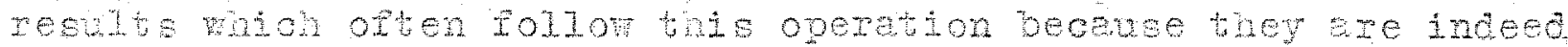
a contrediotion to ali of the knond fects conemine the anetom ane phyeiology of the eympthetio nerve eystem.

Even though it onnot be dented thet olinicen reentes are

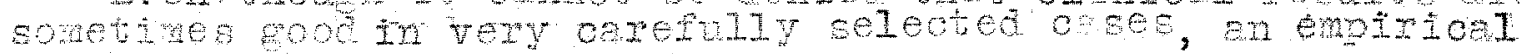




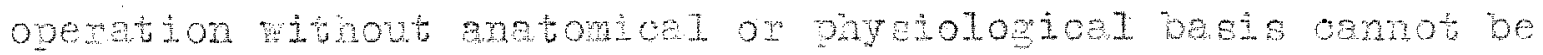
heartint recomended.

In wanoe Leriobe and his pollowere do it ton good neny

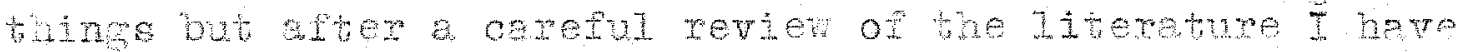
decied thet this is certenty not the operetion of chotoe,

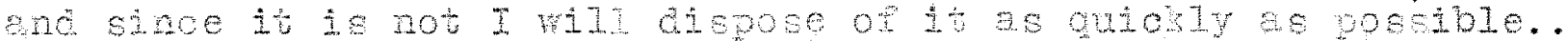

pertarterial stmbethectony hes been recomenced by meny

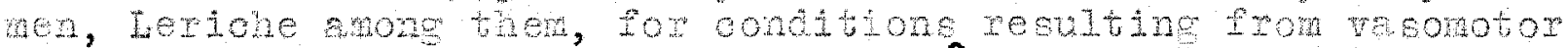

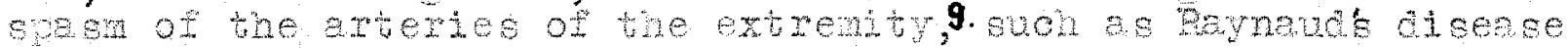

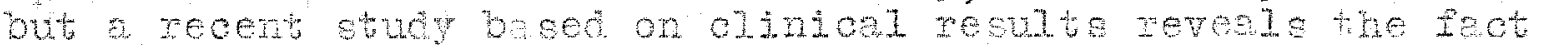

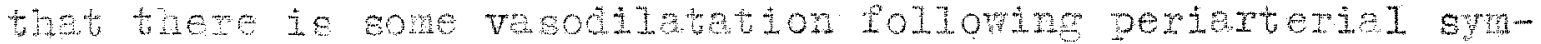
pethectowy of the fenoral antem but that it is ingarient and concluces futher, "Divicion of the man smpathetio twak causes a greater and more la at tne vasodilatetion then periarterial sympethectomy. "13. This fect hes been substantiated by roentren evidence. 14

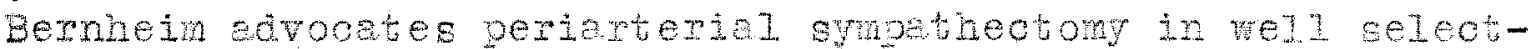
ed case and reports cese of axteriobelerosis as the best mesut he obtained in sertes of twenty-eight case done for

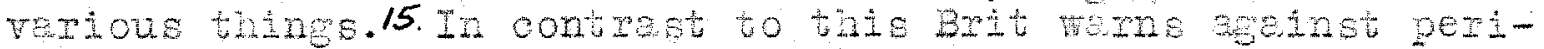

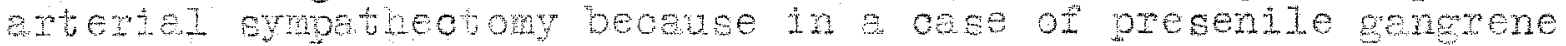
cescribed by hin twere wes exteneton of the gengrenoue prooes

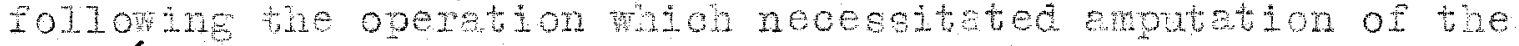
$\operatorname{Ieg} \cdot 16$.

cotte hes been very entmaissto bout pelvio periarterial

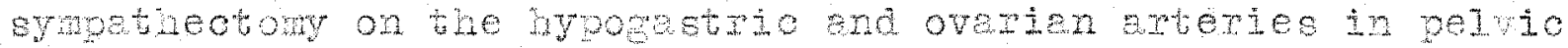
neurelete rath pans in the orery, werue, and uterosearal. Iigment with no lestons on the enitalie. He hes peportedive

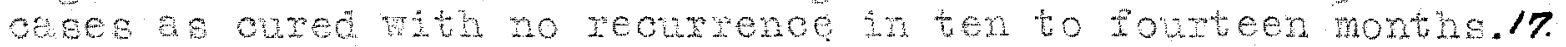
There hes not beer a eufscient nuber of orees reported to evaluate this procedure ruth aocumect.

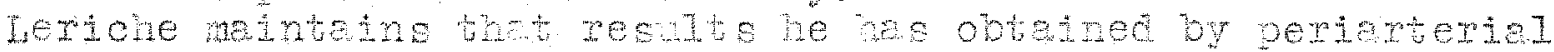

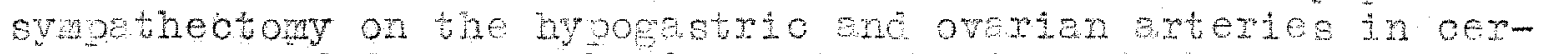

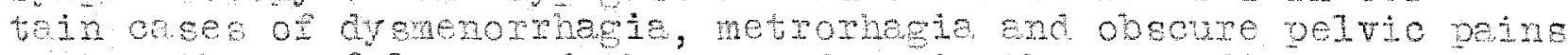
putee the usefulnece of the procedure in these conditions and justiftes apliostion to a whole set of smaromes hitherto unregoneive to eny fom of thereot. 18.

A eummay of ninety operatione on serenty-two petients as

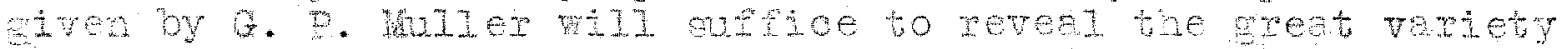

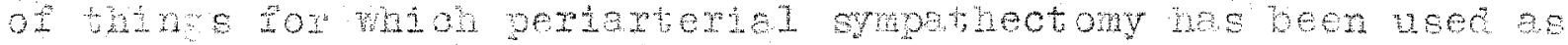
weil se the wherteinty of resute.

Vesolat Diseses

Mrombo-angitie oplit. arteriosolerosis Basneve's

Tropkio conettions Soleroderms

Woers

Wropico

Waticose

Hi scellaneous

Gervicel Rib

wermelgia

Arthrits DePomons

\section{Nunber of gaseg}

17

12

5

1

10

]

2

2
8

5

Benefitued osses

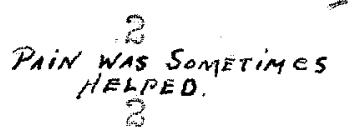

0

I

1 
Viseolieneoue (con.)

painful osteoperiostitis

Eozere, hand

prophid ontroture

$\begin{array}{ll}1 & 1 \\ 1 & 1 \\ 1 & 1\end{array}$

19.

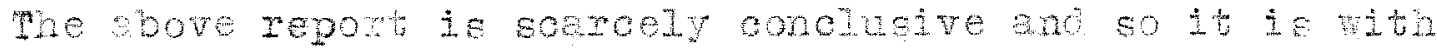
wost of the periarterial arapethoctomies.

Sympetatio ganglionectom and trun resection was itret pertormed by Alexander in 1880 who dic a bi-jateral extirpetion of the superior cervicel geneluon for epilepsy. In 189

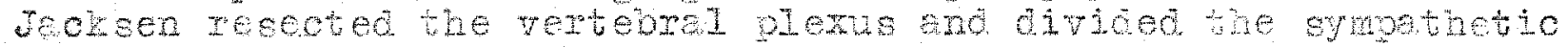
trunk bove ene below the wadle cextion gandion also for epiIepsy. 2 .

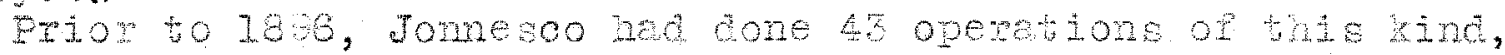

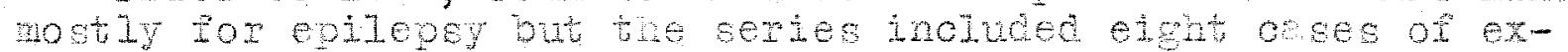
ophtheinio eitre. 20.

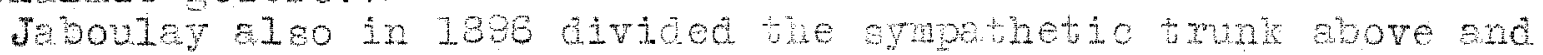

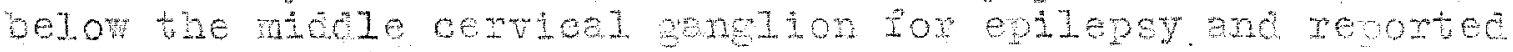
e cose of exophthlmio entre on whoh he hac done e sympthetio eanglionectory.

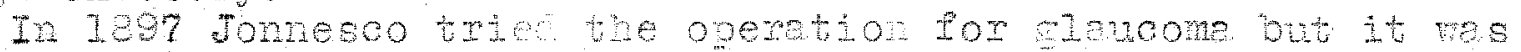
uncuccestul and the procedue hes been discered. 2.

Jonnesco in 1906 agein reported a series of cages, this tha he pre tralve of one hundred and seventeen ceses of idioptine epilepsy as abolutely cured and twenty-ive ceses of exophtheinio soitre a completely recovered.20. ahese reoute in epliepsy a reported by Jonnesoo were remarkeble but etnoe

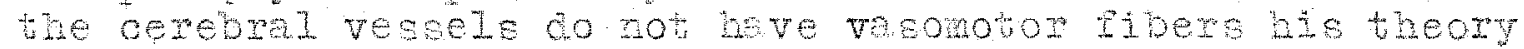
was incomect and the operwion therepore he no anstomitol or phyeiologioel besie. It he lone sinoe been abonconed even Jon-

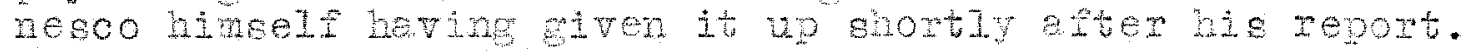

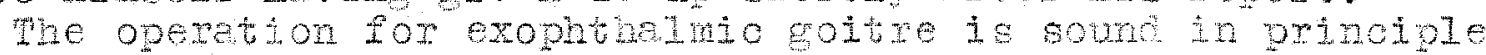
becenee tris type of nyoethymotasn is believed to be due to some anomality of the eympahetio nerve supply, wh thyroidectony

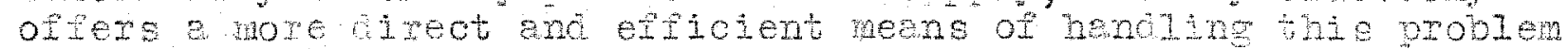
so thet it he been discerded for thyroid dyecresias.

Hon 1906 to 1915 there wes dezinte decline of interest in

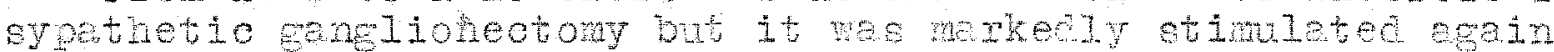
in 1916 by the work of Jomesco who severed the midele and inferion cenvical eanelia and the tixet thoracio eansion on the

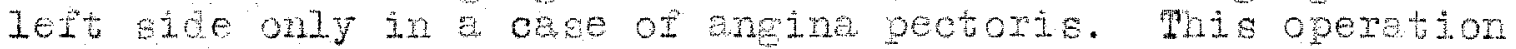

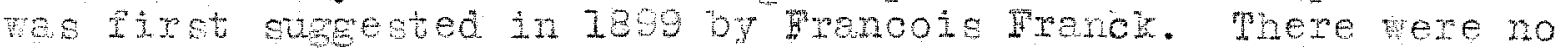

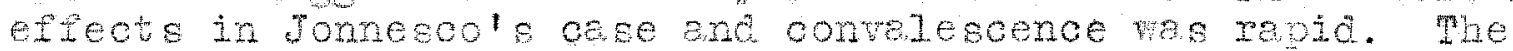
cese fres prononoed as ured five yeats loter. Another osse vos elso Ghow ine pood inprotement. 20 and 2.

The epove opention etimuted a eret ceel of phystologios

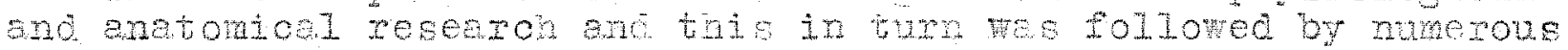

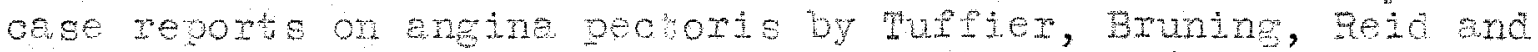

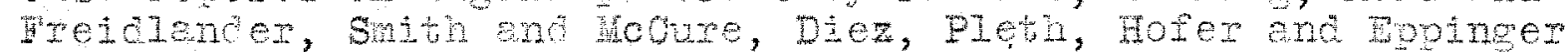

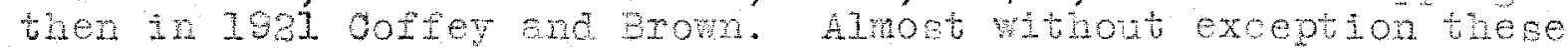
ceses choved improvenent ane many of them were atually permenently and completely cured. 20. 
It his now weone s reoognized orooedure in seleoted ceses of

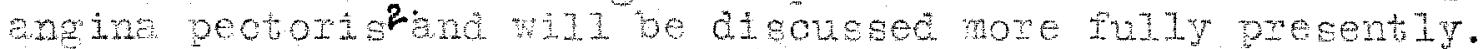

Royele and wuntel in 1034 pertormed a ennothectomy for e case of epestio peraplesta. Mhis vas done on the theory thet speticity wa due to overetivity of the sympthetio nervous system and that in absence of full rolumbar control the

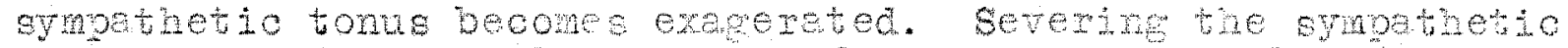
nerves shoud then allow retum of roluntury control buve relieving the eparticity caused by overaotivity os the sympthetio nervous system. 2 . However, ranavel and others in study of the smpethetio nerve evoply of exeietel musele heve one to ble con-

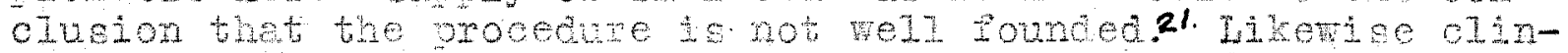

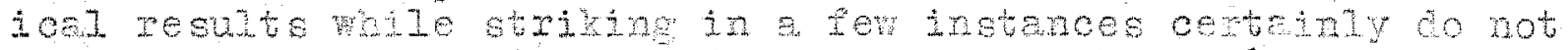

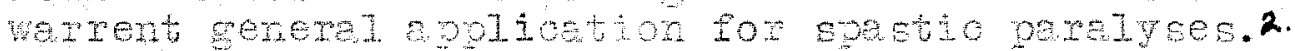

Sympathetio englionectom remisectong and trank reseotion was rext epplife to diseases of the blood vesels resulting

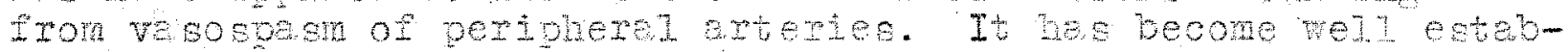
Iished thet extirpetion of the seond, third, and entoh lumbar empethetio enelia end conmuloting remi jojntne the nerves of we seoral plems mut reent in complete eymethetic dener-

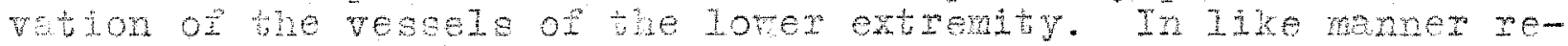

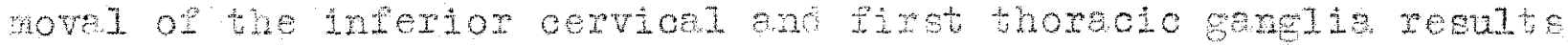
in complete denervetion of the resels of the uper extreaty except were there is th tnongtant second thorecic gangion and then it is necesery to divide the spmpethetio trum belor the gansion. 2 .

It hes been demonstreted thet nomel vessela followine this operation coon regenthein tome but if there is abmomel. vesoonetrtotion befone the operstion then it permenentir ineresect the blood eupply.2.

It mey be well to desoribe the operative techniave of the tro proceduree outlined above, viz. extirobton of the ceond,

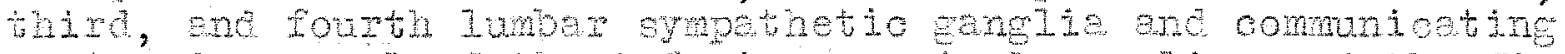
rant and renovel of the inferior orvios genglion and the tinet thoracio (cometines al so the second thomato) genglis.

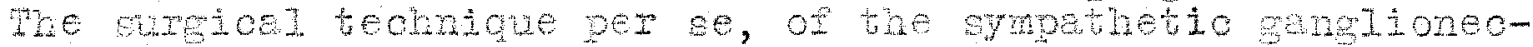
tomy, maniecotory and trunk resection ie not especially dificult

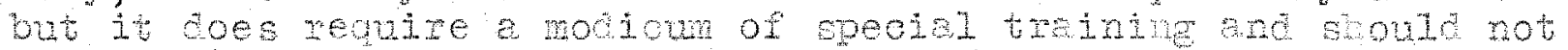
be done in the routine of buey eureen's by.

For renotal of the secone, thire end foumb lumber aymothe-

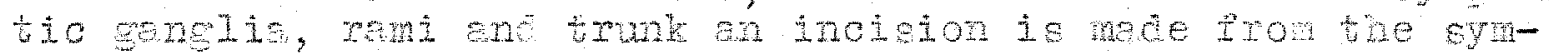

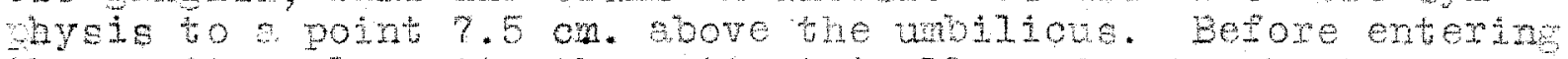

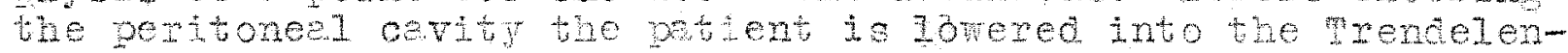

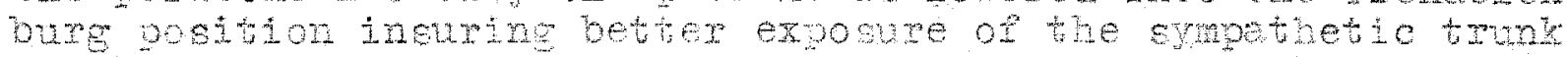

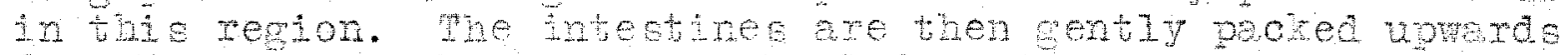
inst on elther the rignt or the left eide and then on the

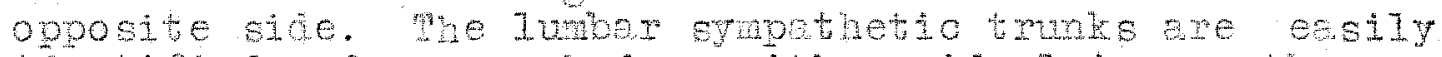
identived and appodod on either side lying on the vintro-

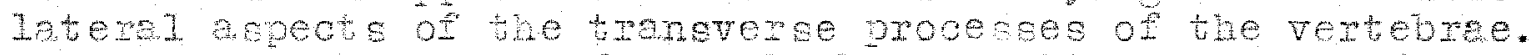

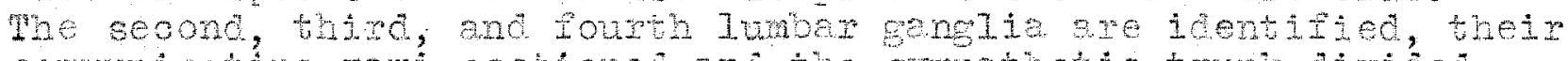
communtering ram seotioned and the strpethetio trunk dived and removed. We chief daners of the operetion are, treune be-

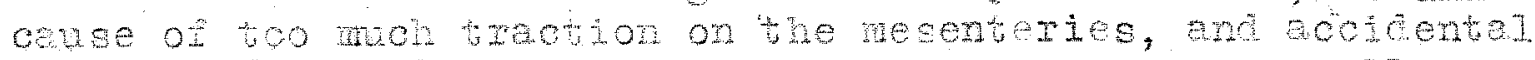
rupture of an intertertebral vesed out these ere usueliy es $12 y$

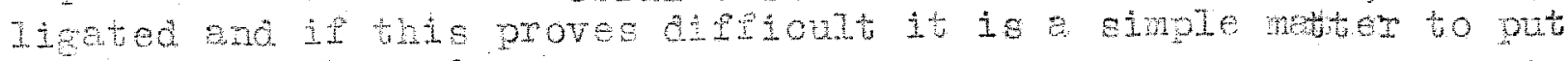
or estrei clemp. 3 . 
Soz menol of the inferior cerviol and firet end second

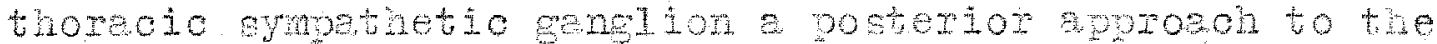
nedisetrun is the metbod of ohoiee. A me line doreal inotoion Is made from the sixth oeviod con to the pourb thoracio vertebree. Whe seond thoracie vertebra and rib are identrited, the trensveree proees of this rib is renoved and the secoma rib three on. laterei is resected 22. Whese ane rewoved witha rongeut. The plevre is thus expoced end is discected emey by blunt dissection. The sympthetio trun and genglia ane non

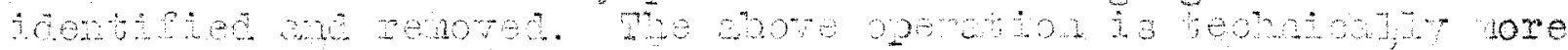
afficut then the precedirg one but wen properiy done there is little shod end complications are relatively infreduent.

Po discuss the indications for synpatnetio genelionectony, raniseo-

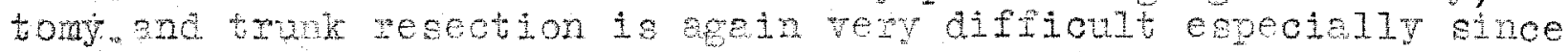
I heve pronised to doid controversy. Merefore in a nore or less

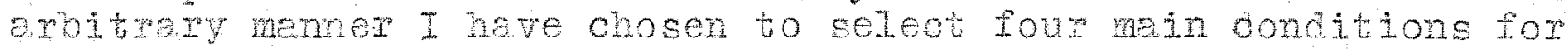
Thich symothectom is of nndiputable velue, inceed in sone ceses ie entrei curative. In all four or these conditione not only wes the petient helpless becense of ats etrifotion but his prognosie wa hopelese berope the advent of wreer of the antonomid hervous syetern.

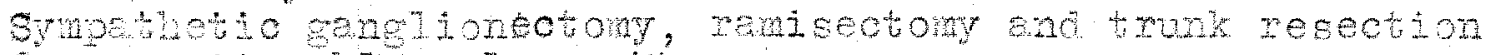
ie of unguestionsole velue:- in

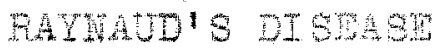

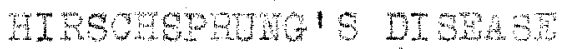

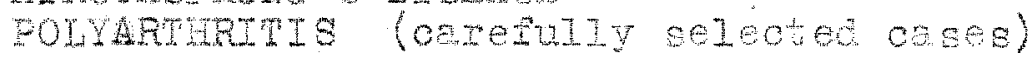 \\ MOLNTA PFOMORIS
}

Reynad's disease is a clession example of vesonotom epesm.

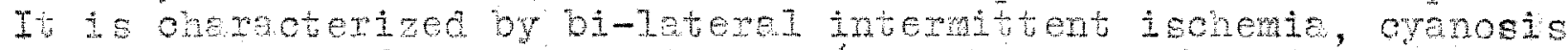
anc ayperemin of the exwemities, (though it may be of en intexnel vessel) and the resospesio brocke ate usuelly ether orechuitated or mede roree by expobure to cold and emotionel alsturbences. There is cheracteristio ebeence of orgenic disense of the veseels. werefore the radiel end arselis pedie anteries are pelpeble.

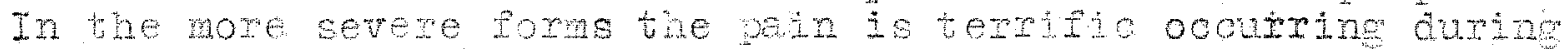
the the when the extrenties are red end suollen and frequenty leede to gangrene of the digito.

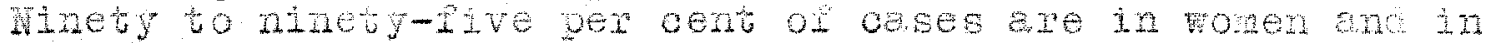
s pexiod of lise before the arteriosclerotio ege. this abnomal

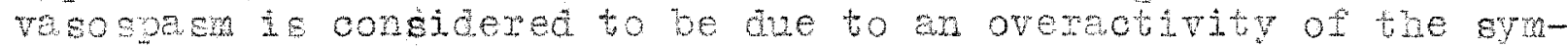

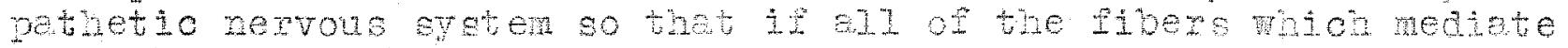
Gympduetio impulses to a fiven extremitu wero severed then re-

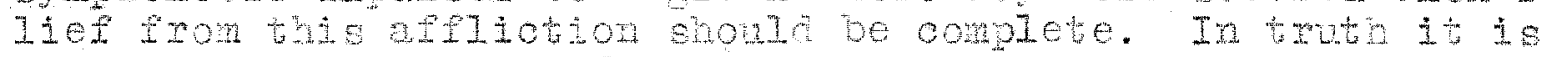
complete ane pemenent folloving sympethetio enelionectomy, ramiseotory, and trum resection 30 we are then able to comelate

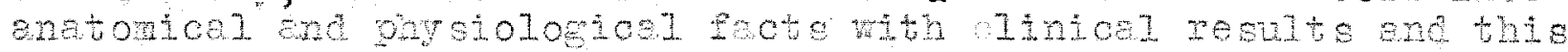
Is the desireble conopt of enreng of the atonomic nemous bysten thet I wish to erelop.

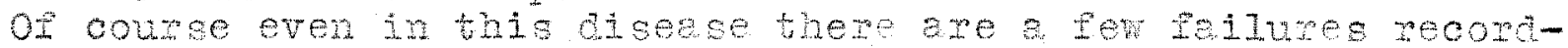
ed but these are no doubt une to mistake in degnosis and improperiy selected cases.

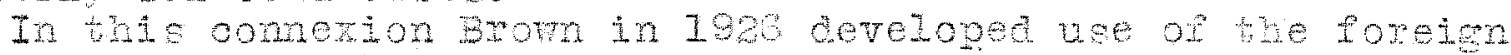
motein mestion to detemine sultabtitty of cases for operetion. Foltome foreign protein injection there is dilatetion of peri-

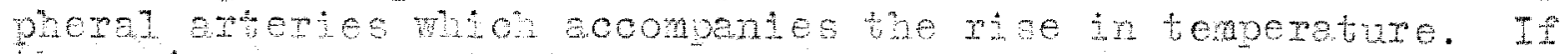

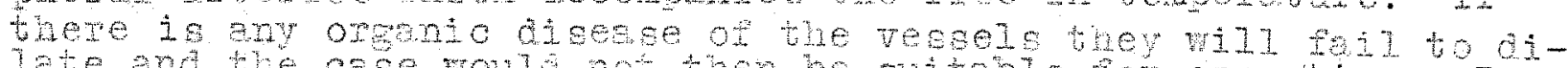

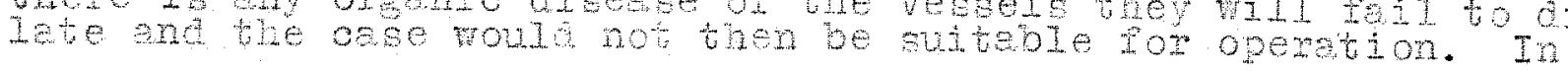




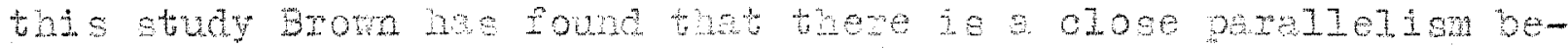
treen the elovetion followh woten injection and thet follow-

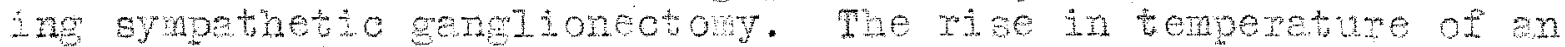
extrenty should be tro or more times the wise in mouth temper-

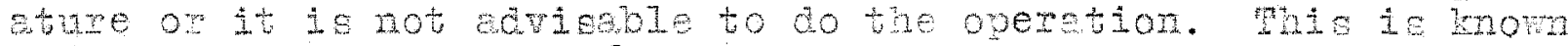
es the trascular incen". 22 .

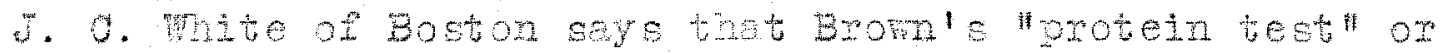
vescular inder is not 31 raye relibole. He hed developed a rethod

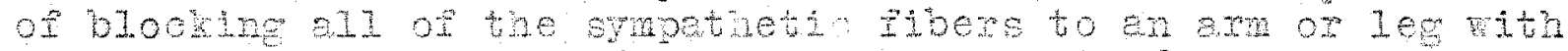

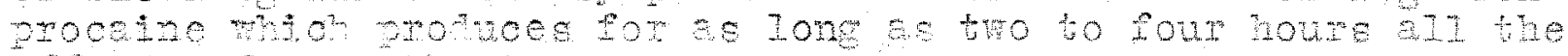
effects of sympthectory.

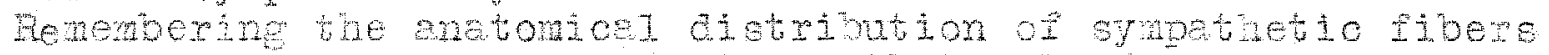

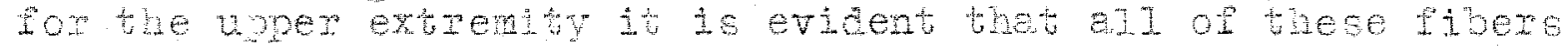
could be completely blocked by injection of proceine alone the leteral border of the bodes of the fixd axid seond dorat vertobree.

It is possiole to ceuse vesomotor parelysis of the lover extrenity by a suaromoid blook reaching to the level of the eixth thoracic vertebra, by injecting procune along the stces of the lumber vertebrae, or by bloking the soidtie nerve, ix any oese Intermption of sympthetio pethays is complete and the resut is quaditutively enelogous to thet wioh will obsan following operetion. The petient on reentze whet he rey expect dolionting

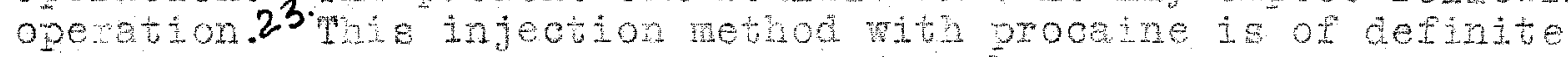
dienostio ane prognostio velue end is beine uee cute extensively at the presentivitis.

Aocording to Brom and Ason a patietn with Pavnad's disese should underso an operation whon:

smotons are progessive.

mopho chenees ere develophis.

The petient beomes iroegeditoted.

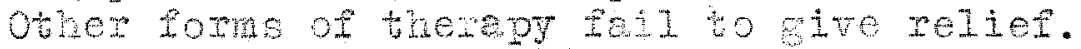

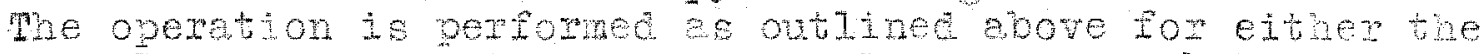
uper on lovere extrentites. Whe results are remerable, there is immedite relief from pain, the sin beomeg wam pink and dre 0ld uloers heel repidy bnd netls resune their normel erowt. potiente are dole to return to their usual work. Sone of brom the Ascon's petients have ben observed for move then four yens rov and relief he been complete rom the whole of thie period. The skin of the atected extremity remetne dry but this is relieved by aplication of olive oil or cooos butter. Homers synrone wisk ie vevally present when the uoper extremitios heve been opereted is of no consecuence if th in bi-lateral but it ie froublecone it th 18 uni-laterel.22.

Sympthetio eanelinectony for ocolusive artexiel diseses ovon as erteriosclerosis and endarteritis is of questionele velue, certanly the retionel for the procedure is not elear. The operation in these diseases is beseo von bhe destee of vasospen of the mooclued collateral tessels.

Goores ar. Brom states thet results in thromboneitsis obli-

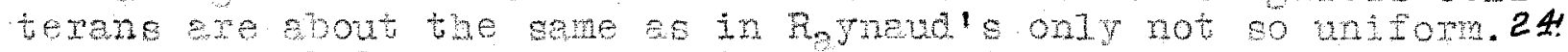
Hany othere beliere thet results 270 so disepointing thet openative measues ere to be avolded in bhis diceses. Brownend Adson stete thet the operation shovl not be dore is relief erom

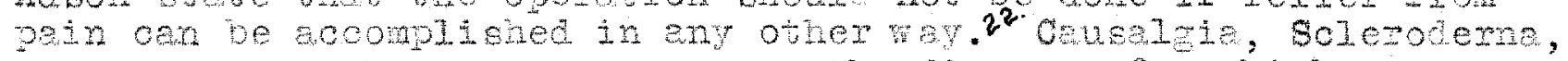

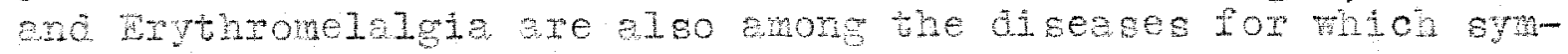

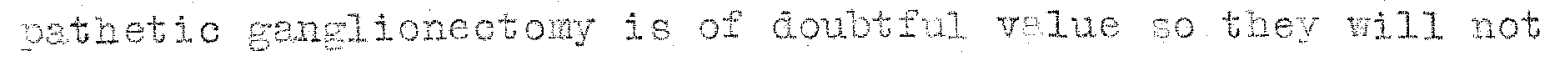
be considered. 


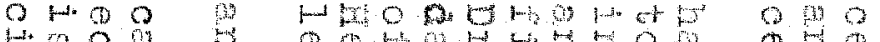

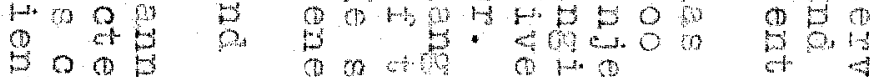

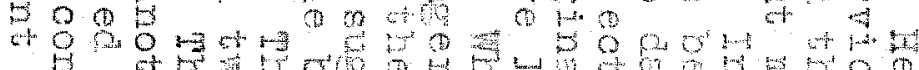

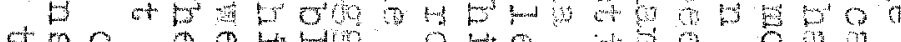

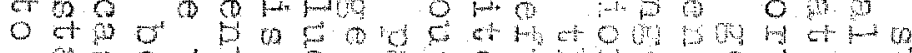

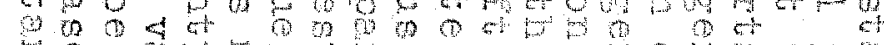
sकo

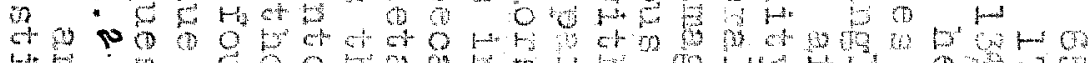

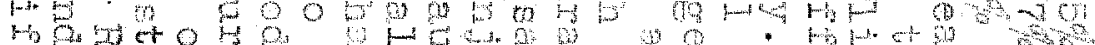
कo

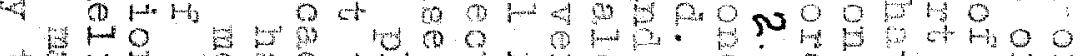

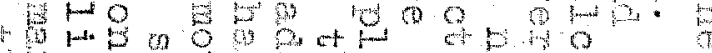

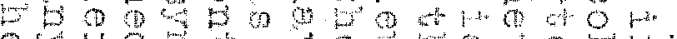

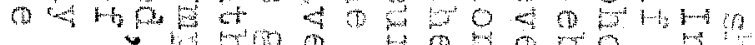

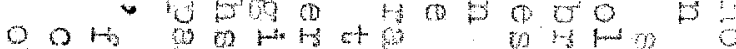

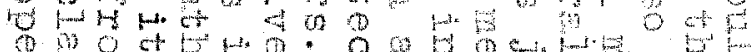

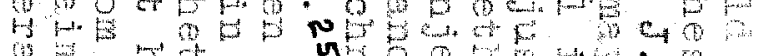

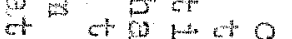
1. 0 b 0

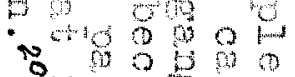
in. $\mathrm{pos}$ I $05+400$ 0 a 0 0 का

$3+948$ $+400$ 000 $n=y$, का 0 . 0 a $b$ ros

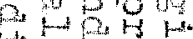
098 $\rightarrow D 0$ $8+290$ $+\infty \mathrm{po}$ का क्षम

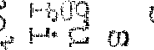
O $1:$ in $\mathrm{w}^{4}$ ming wh $D-b$ y at bes $n$ (1) part on

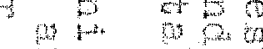
a $9+4$

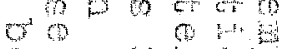

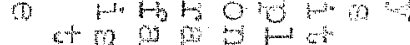
$-0^{\circ} \ldots$ o 0

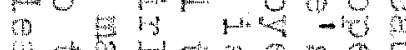

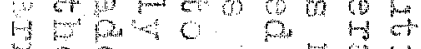
$s a r$ o 8 a क क a the s $80 \omega+4$ 400 का H. 4 का का का

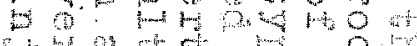

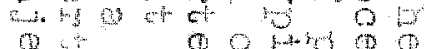

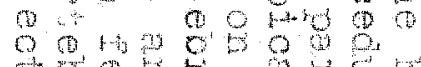

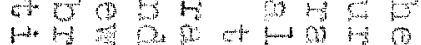
$0 \quad 3 \quad+0$ क $b$ to 0 H w Hotation of का

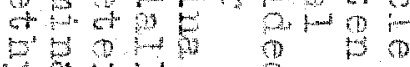
it
(1) $P$ a

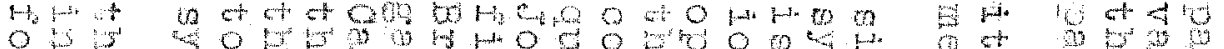

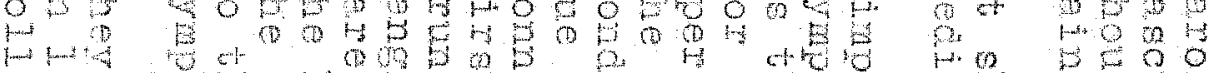
q

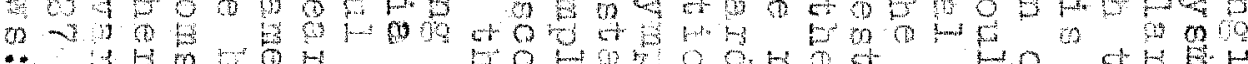

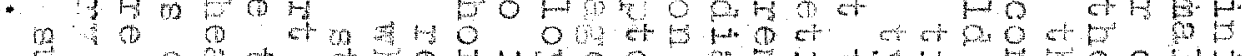

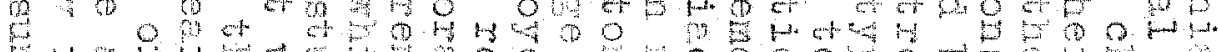
9 w

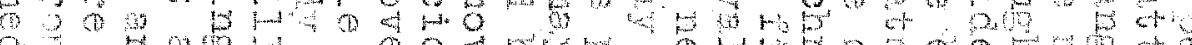

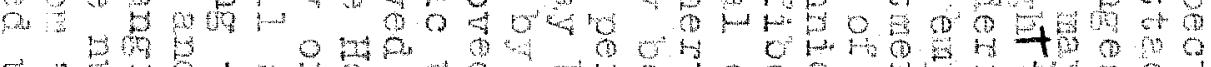
एक

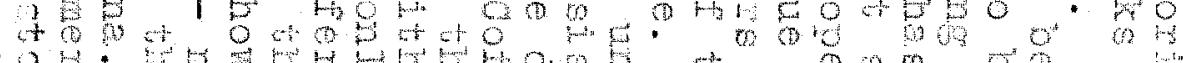

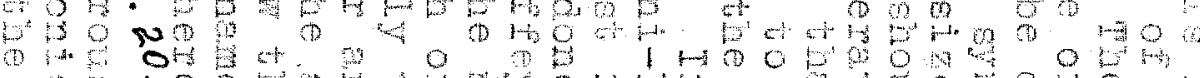

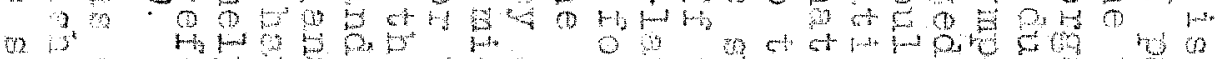
औ.

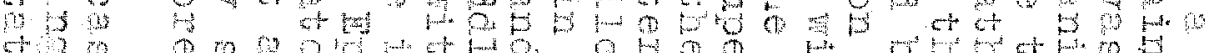

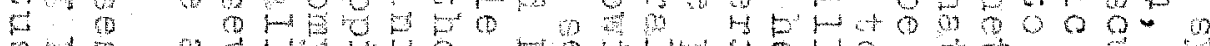

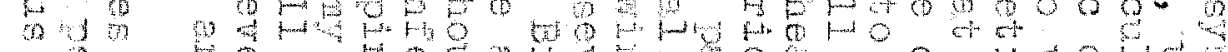

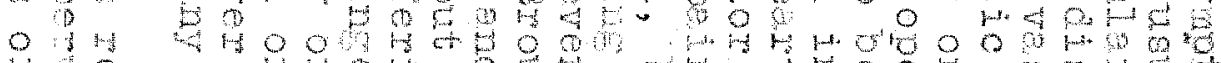

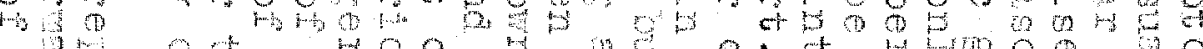

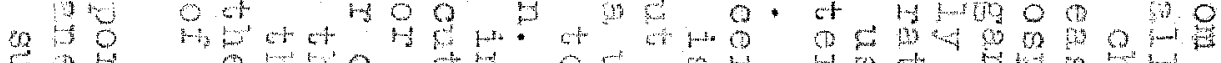

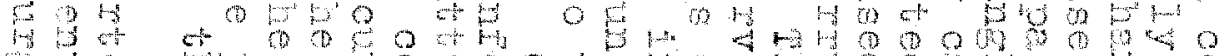

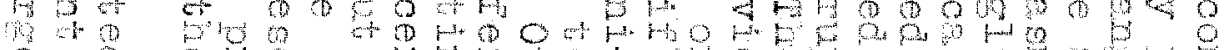

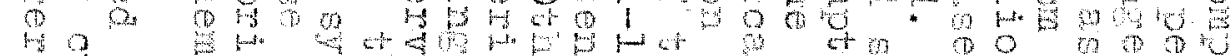
$40 \%$ op H. का +

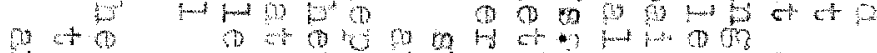

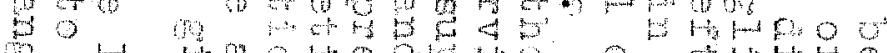

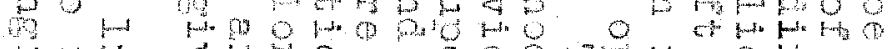
H.

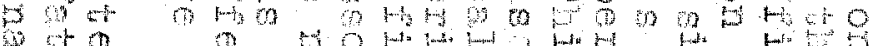

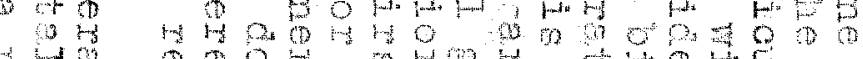

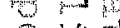

$8+x$

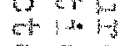

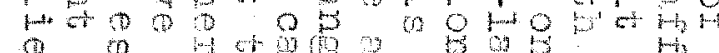

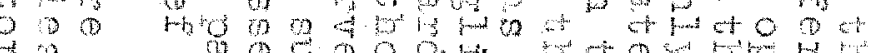

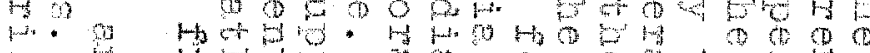
6 क

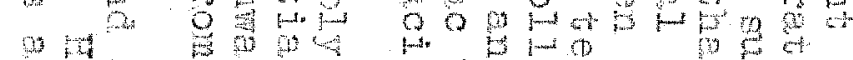

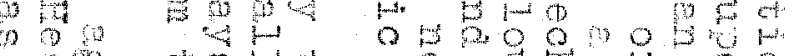

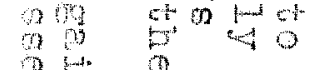

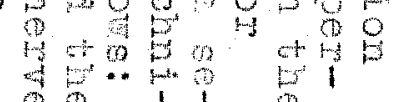

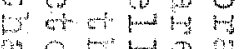

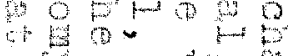
th 0 का $\log _{0} 00$

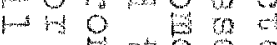
an

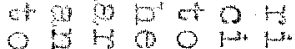
ox 4 का 4 an

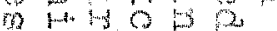
की 00

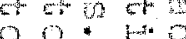
i in 30 $810+40$ 
not heve Itved enymy and pemment peliez from ouch a pan-

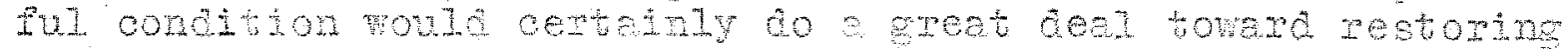
an indridul to nomel existence wheres whont the operation

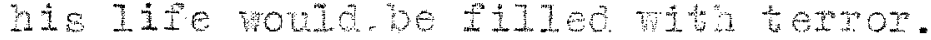

Sone of the most striking thinse thet thete reed concemine sureery of the autonomic nervons stetem have been in conection

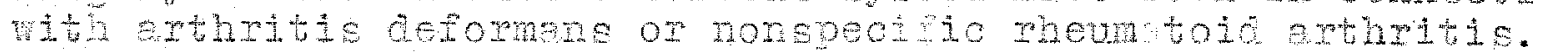

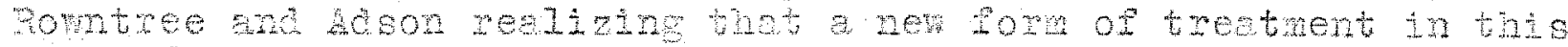

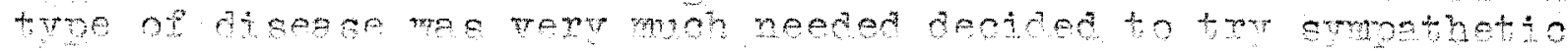
ganglionectory on a ose of thelis.

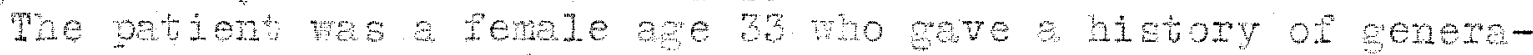

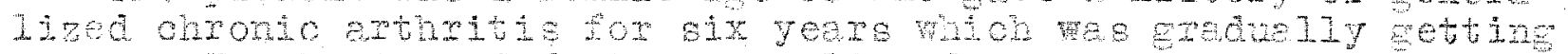

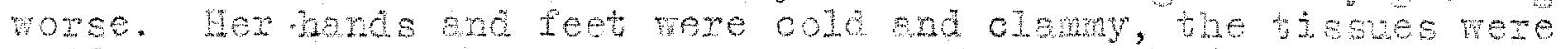
utfy and there were trophio chenges. We apes of cyenoss and

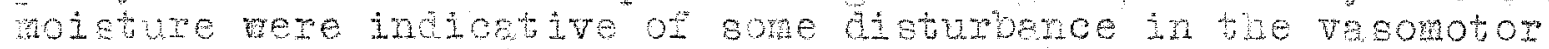

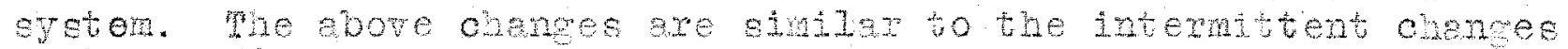

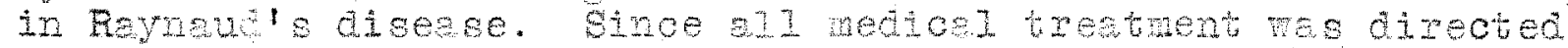

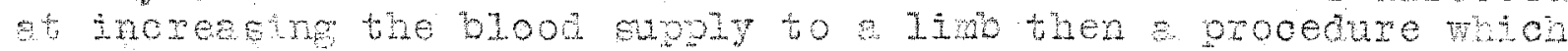
rould permenenty do the shoule etrome some relief.

the petient underwent e period of obervotion in the hosptos wh al medond treatuent mes of no avel.

Where mere exroerbetione of her condtion, it wes worge at menseg. She had gutines and sweling of the interonelanged. jotnte of both henes, then the wrists then the eloows, enoudere,

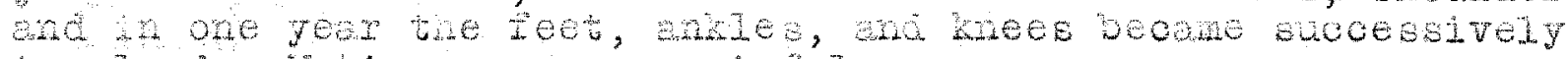
involved. Wotion was very patulu.

She wes to oe disnised from the hosptid but se beged to here comethre tone so the socoma, third, che fourth lumber genelis wth the aypetaetio trum on botn sided were remored.

Improvenent followine operetion wes pronot and actonishin. phe peet became wath, dry and pink. H sont time following hex operation che welked two miles with entre exedon from pein. wor two-an-a-helf yeste efter her operation the patient end che Elt

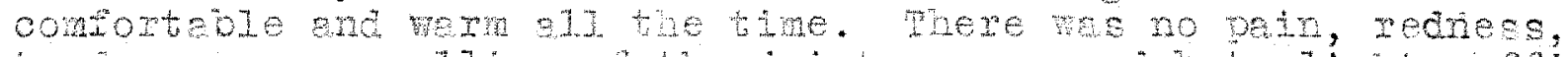
tencenese or anellang of the jotnts concerned but slight pupi-

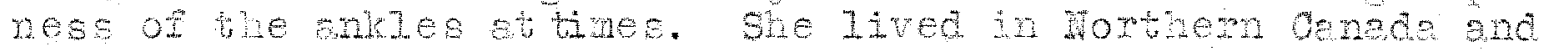

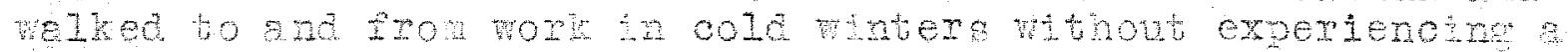
susecetion of recourrence or artintite.

Muring this period the jolnts of the upper artomity were

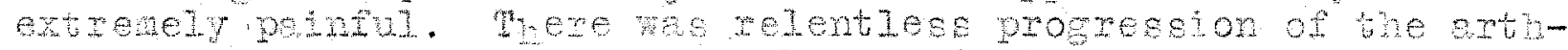

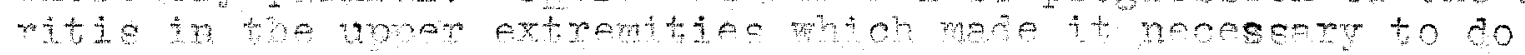

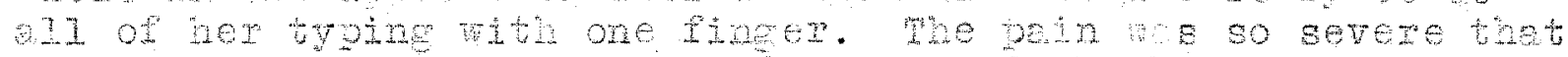
the petient cond no longer endure it and sne ned a nervous break-

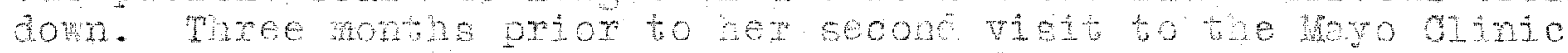

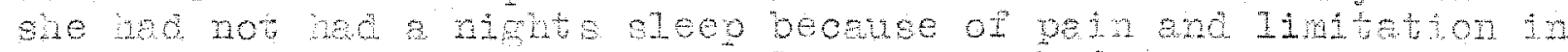

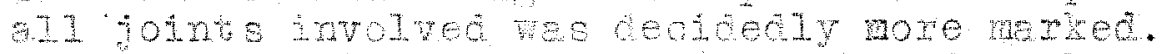

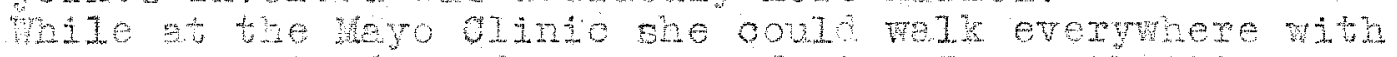

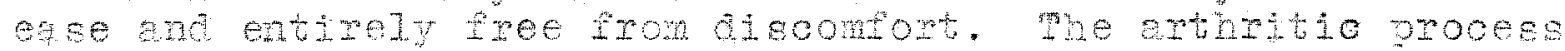
her aectedr progresed in the hends. phere was sone etrophy ot meajes ond befinning unar deviation. me hande were cold and dewny, cyenotio and noist. phere res no wip in either hond - che cond mot mare a to with etther hand. The zingers were

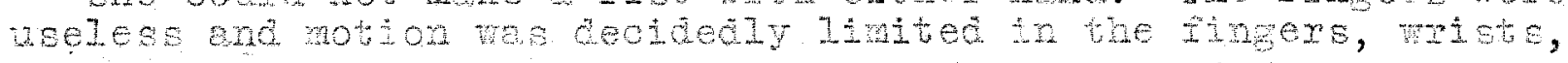

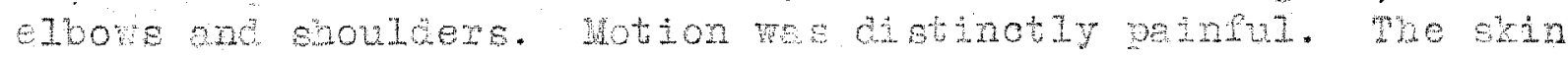




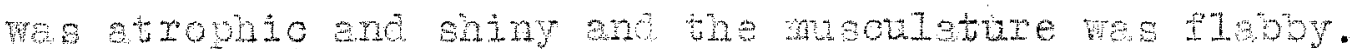

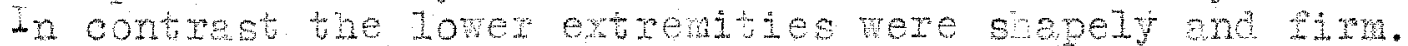
There wes no pain on motion, only alight bating in the anles end knees but this wes not ecompented by pen. The feet were wam exd dry, the gutin wes nomel an texture and epearanoe. It nes $100 \mathrm{~s}$.

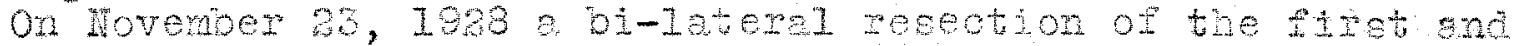

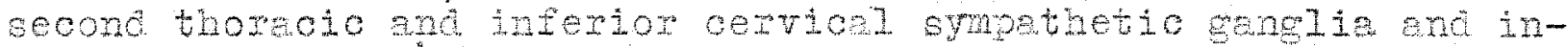
tervenine trunk wes done. And imnedtately followne pperation the hands bedrne perm an dry ane a nomel pun color. sne could whe e fist and grip a person's hend.

A bi-latemel Hornet's sydrome developed but the did not detract irom rer appearanoe.

For the firet iev daye eter her operation gine suffered a

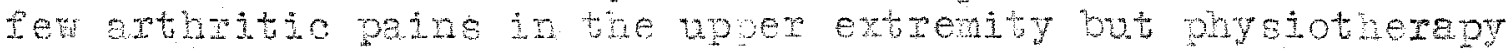
geve prompt retief for these. When the petient left the noeptan

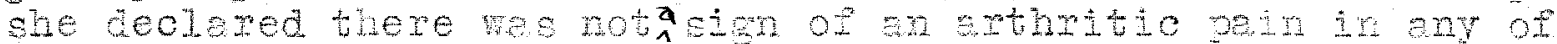

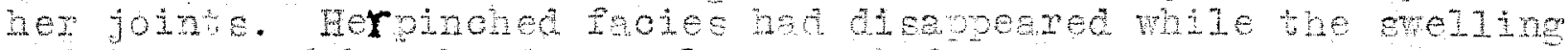
and tremor of her hends wes less meraed.

Whe rete end rhythin of the pul se were nornel. bne hed one

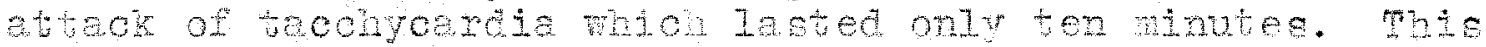
phenomenon hes bech oberved in othet osses of cerwiothoracio eanglionectony. Sweeting wes absent over hine conresponding arese but could be produced by amintetretion of plloosmotne.

He wee In tempereture of the hence now oorreaponed olosely whin the temperature of the feft atter the firet operation. whe elevetion of temperature of the fets had been fully sueteined for a pertod of over three years.

Whe onculation wes very good around the neils, there we no

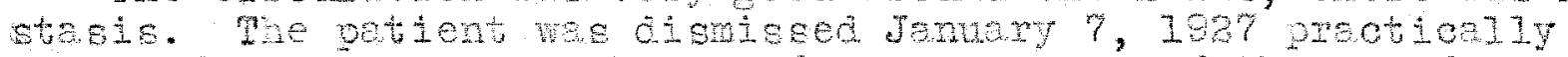
cused of her artintis though of course, some of the manifestetsong of the old process otin remetned.

Whe Festing and $10 \mathrm{ses}$ of tone of the muscles togevher mith

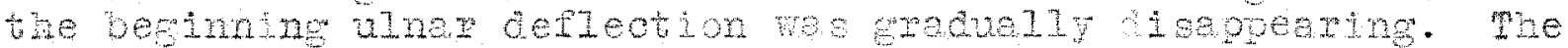
hands were sott, dry, pink and vem wam. wer noils hed fomed thet vere veriectly norna tn appestrnoe.

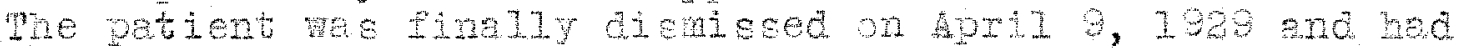
gatned eixteen pounds atroe hey first entranoe.31.

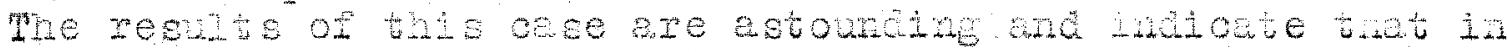
certin tyes of athxitis there is an overectivity of the ayuptuetio hempus system producins vesotor disturbences with cole, clamu, perspine hande and contributing to mecular

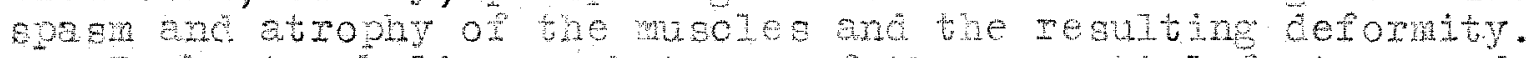

pemberton believer thet one of the essential feetures of

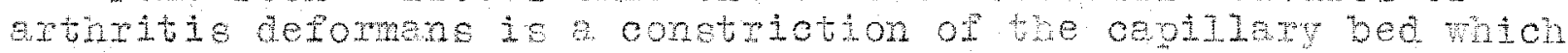

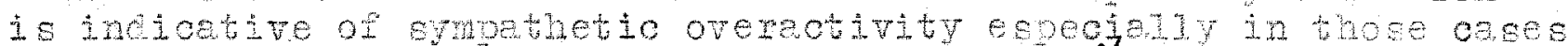

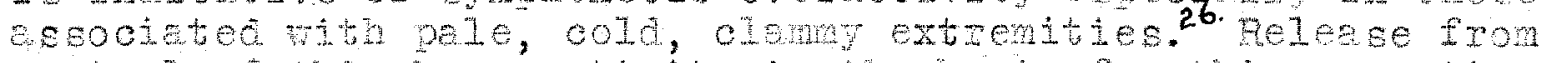
control of bus hretectivitit the bests for this operation.

G. R. Spurine repotte tro ceses in onldren as completely

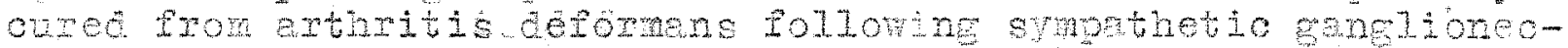

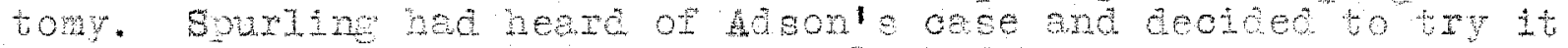

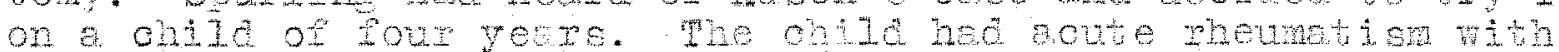

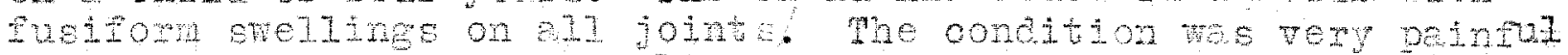
and the extremitios rewe cold.

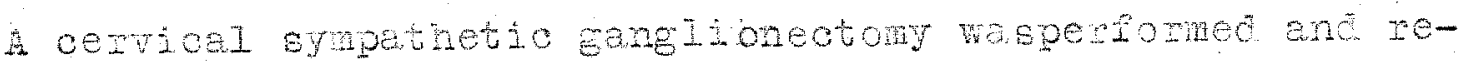




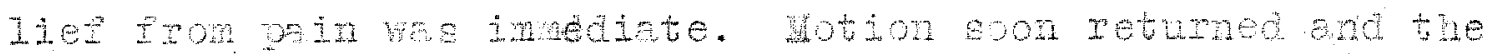

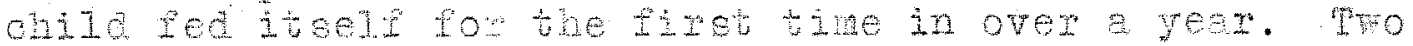
and oncheli monthe Ieter a bi-laterel econd, thatr, ond foumh

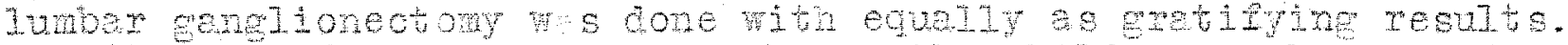

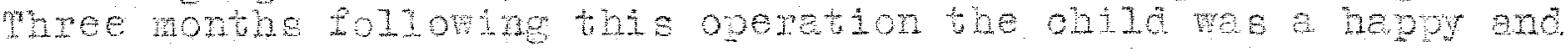
contented inctiviturl.

The second petient also a chis, ege seven, we treated in

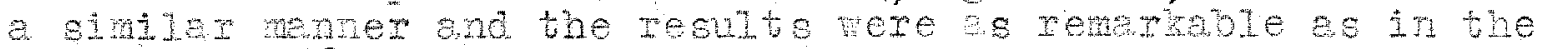
inst cose. 27

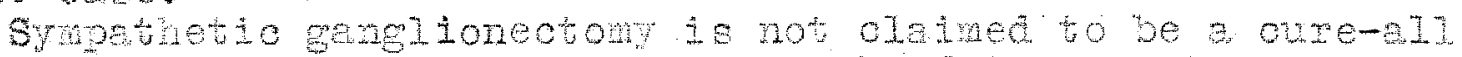
for all types of axthitis. It rould be folly to attempt to crie ofses whth adranced bong chenges by tha mens.

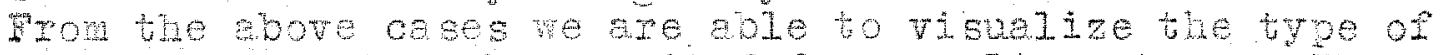

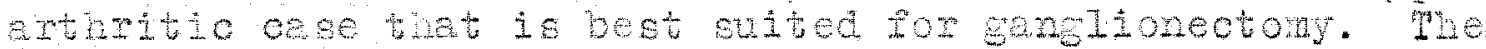
most important item in this fom of treatient a the oroper election of cases. The nerve trunks will not wegenerete once they we out and removed so there is no reason why relief oboun not be permentent.

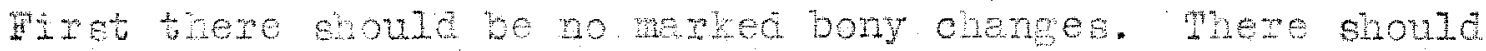

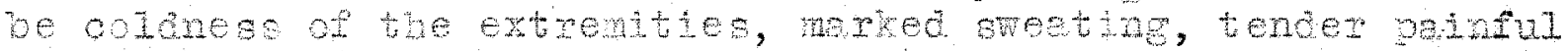

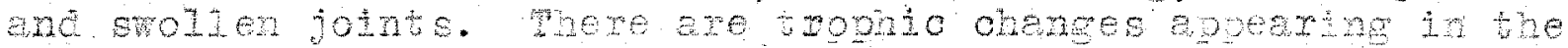
mucoles, stin and neile. Al ceses bould be oerefully studued.

Wha fiele is one of the not proming in the entire soope

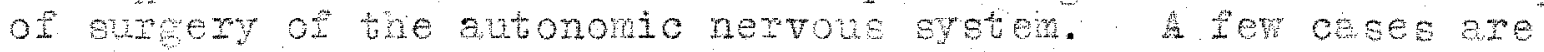
by no mene concustre but they are woet encourenge ond most wer are egreed thet the procedre 1 a very helptul in propery selected ceses.

Whe fourth condition for which aypothetic genglionectomy, tanj sectomy and trunk resection hes cone to be z reoponized procedure is regeoolon.

It is now belitered, in lipht of recent observetione thet

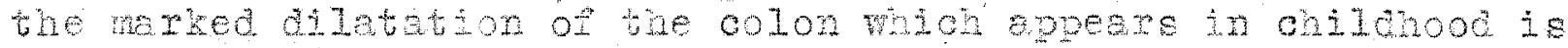
the result of hypereotivity of the sympthetio nervots syeten.

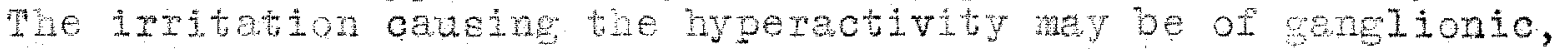
pregenglionic, postgenglionic or nost provebly, centrel origin.

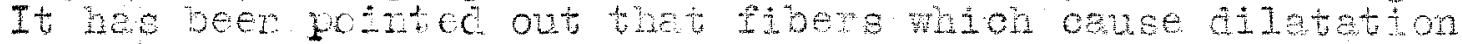

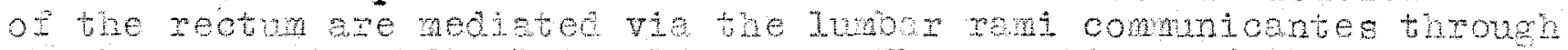
the hypoestic and pelvis plexuses. Then section of the entine

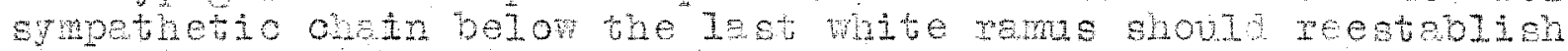

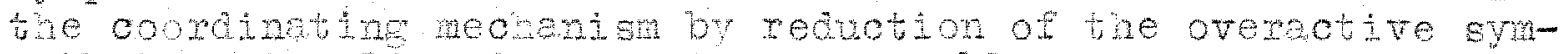

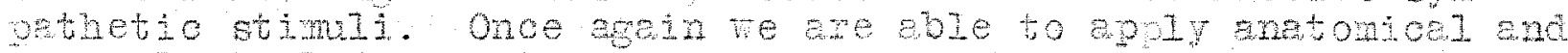
physiologtoel faots, to pediot what may happen, and whet is even more protifying it doeg happen.

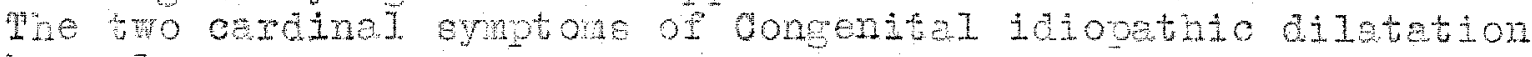
of the oolon ane:

Oogtipetion

Distentor of the babonen.

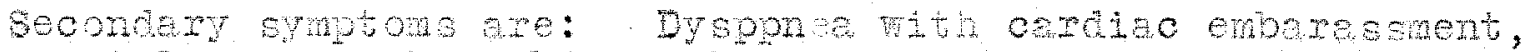

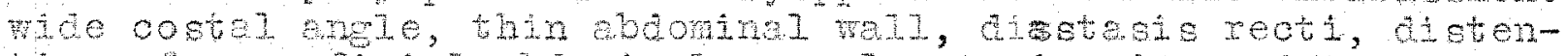

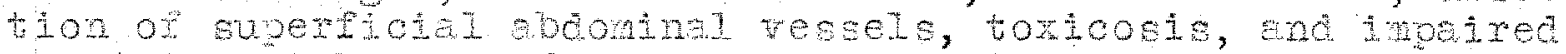

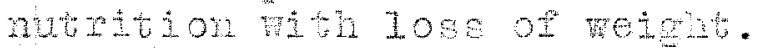

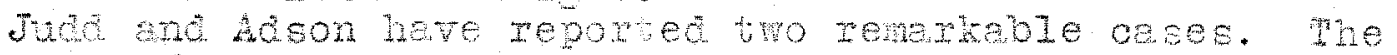

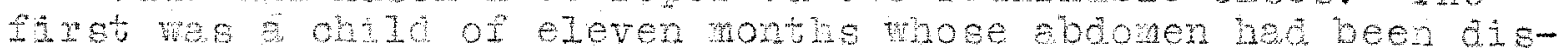
tencer prom olrth. It hes elwys baken enemen and petrolerer.

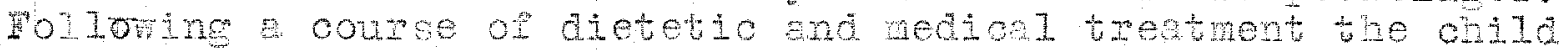
continued to lose weint. Fnemas be finaly falled to produce

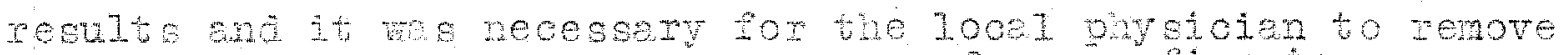

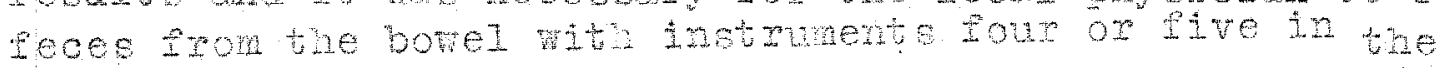


two watre perious to entrence.

Adson pertoned a b-leterel lumber eympthetio fengtioneo-

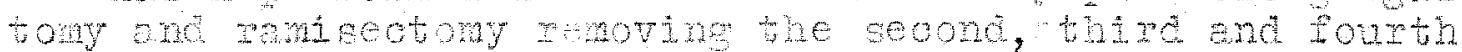

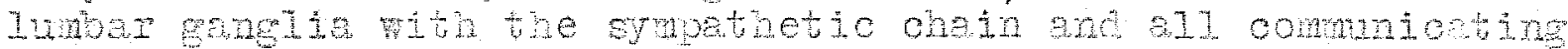
sent were sererea.

me post operative cousee we nomel. oily enemes were eiven for e per days to cofter moon mentrenes and feces and

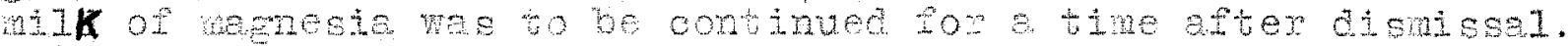
In one month the mother wrote the chad wes monderifu in every wey. ho bowels noved daly minout enemas or laxetives me stoole rere nomel. By the ond of pnofher month the chid mes stil better enc in two veeks pervioue to mother s report she had sitren only one soap snds and one oil enena. Me second oese vas six years old ane he hed complathts siniler to those siven ebove. His post operetive couree ras

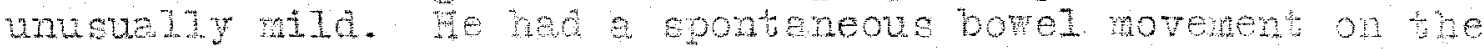

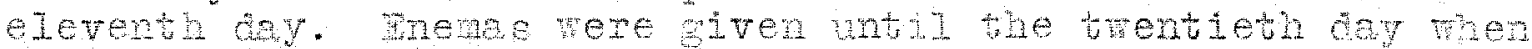
they were no loner neoesery. 3.

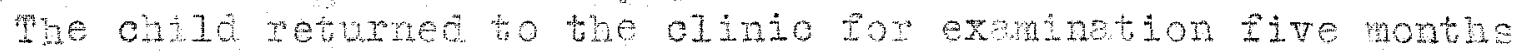
later and wis aotivity was now pood. Be had one on two spontan-

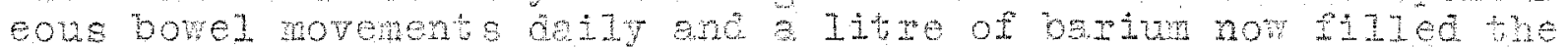

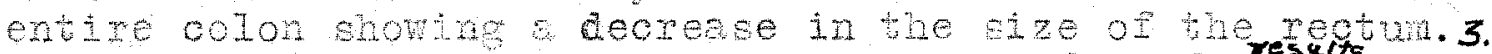

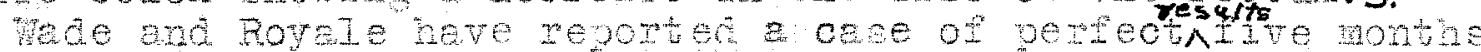

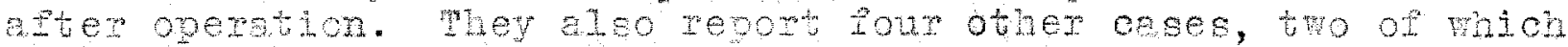
trexe good and two of whin were unsetiafsotory. 2.

There is one other arour of ceses whoh of ter prontse to sureory of the eutonomio nervous gyetem. Many men believe twere extsts or enould exist a surety of pein which is cartied out

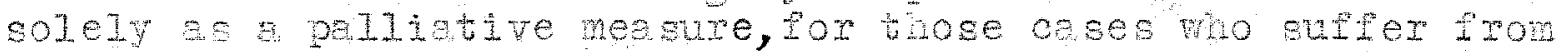
pain even though they neve undergone other types of ourgery. 2 and 2

Von gaze in 1923 ptotured for the propesion fre case of

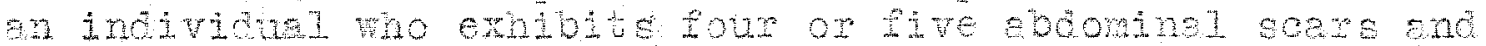

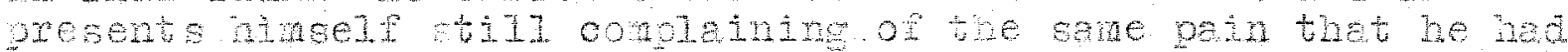

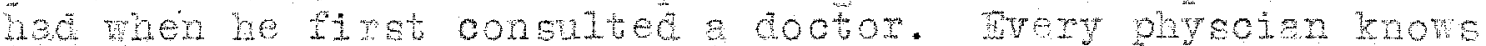
seremel of auch oses. As a dule it will be found thet these

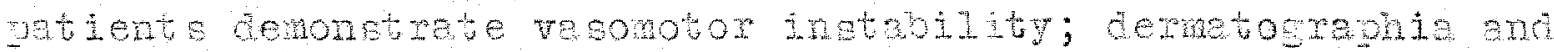
whel Iorisetion on irritetion.

He constaer these oses as intua abonind vesomotor and enteromotor neuroses in wion the semente of the vegetetive

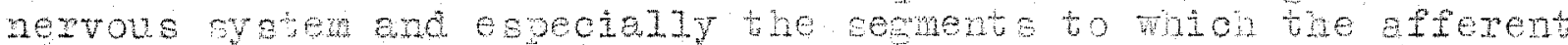
and effenen pethe moning in the remi commicentes belone are

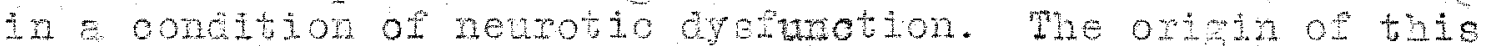
dyetumotan nev be peychio tratume.

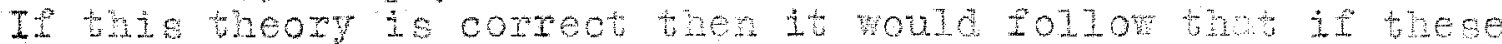

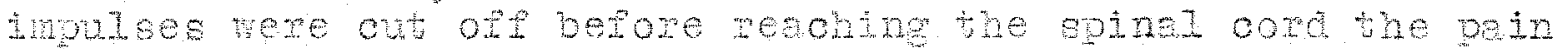
would be reliseved.

Amy atomot Iine the abore of course necesiteter an exect loodizetion of the pein as to semente and eo he injected novo-

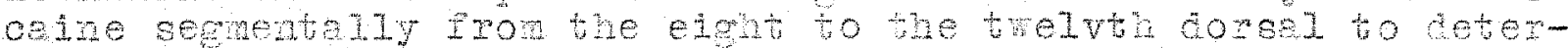

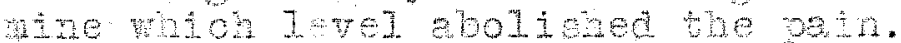

Ther Ton Gaza cut the romi commatoentes ot whe proper level removing aleo the postexion root manjia. His obse nesulted In oemenent oure.

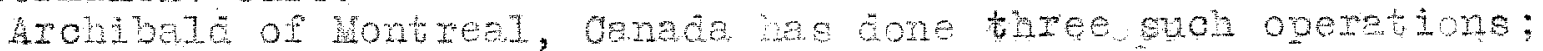


one ended fetally from a bi-laterel newo-bhorax whie tro gave perfect resulta.28.

Surgery of the autonomio nervous syber for relief of pein ise field whoh ie worthy of etudy and reseroh. More expertence wli eneble a beter selection of caes.

Wonen and Thompeon esy that operations upon the stmpothebios

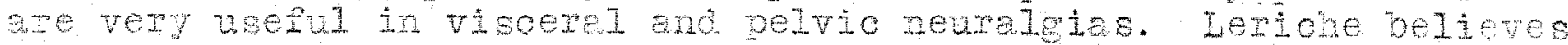
thet the greatest acrance in stmpethectomy ha been in grnecolom, were neny petnth pelvio oonditions, even inopereble cercinone of the ofruiz heve been atuelioreted. ir.

To ade a snst amount of porsonel boud to this atrole I beve traen whe troube to elect three ceses - one each of the ionr

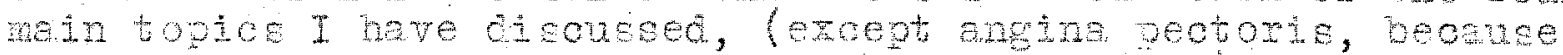
no recore of this operation oond ba found here, thet have been operated in onene.

\section{Reyneud's.}

The firet are I wa to reportwas Dr. Kesen's. I hed the

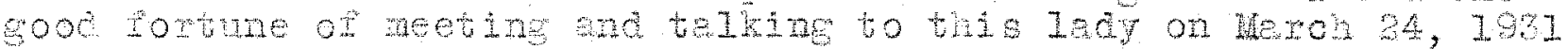

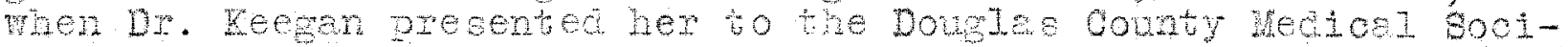
etiv.

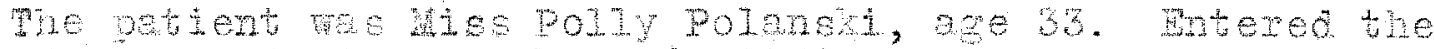

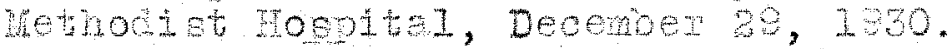

She geve a trptod history of Reynad a - - intermitsent pal-

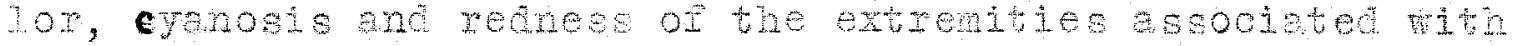

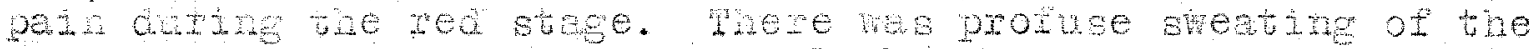
extrentios, radial pul se wes plpobie but lese then normel.

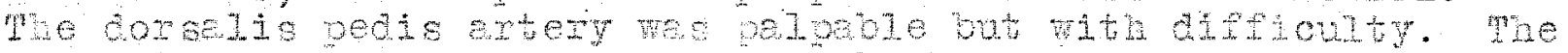

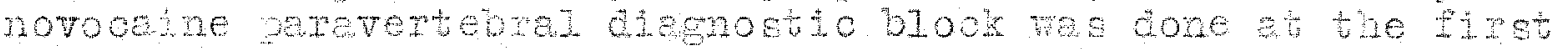

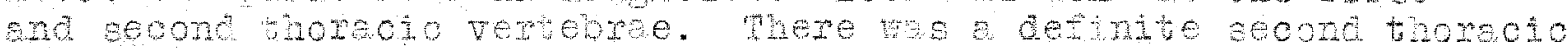

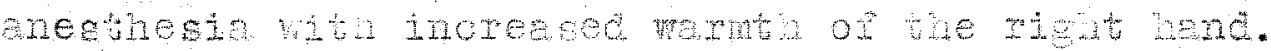

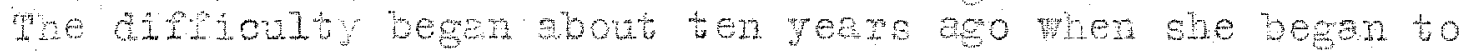

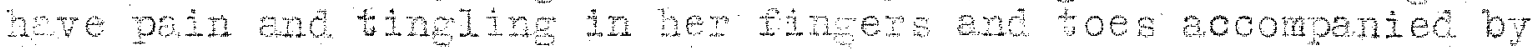
discoloration - - blue - greenish to white - - red to pink.

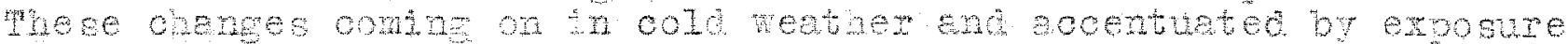

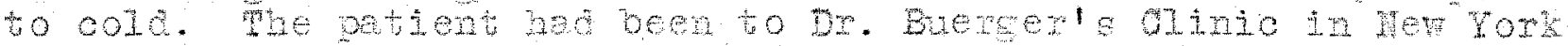
dity mathout reliet.

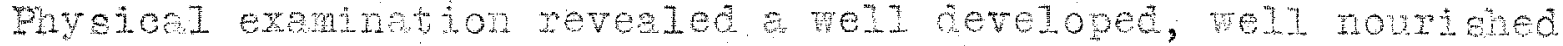

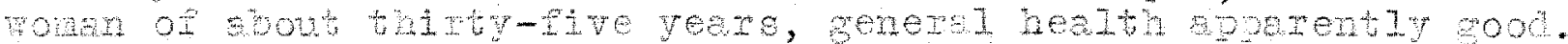

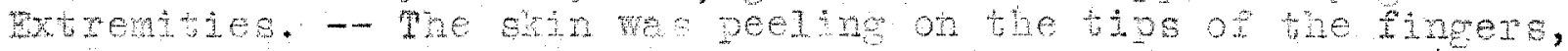
the we ragne of the natis. The tips of the fingerevere di-

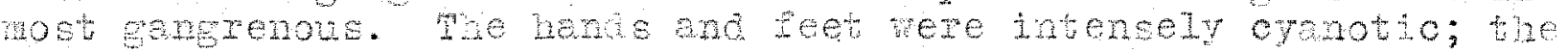
entseres were pelpable.

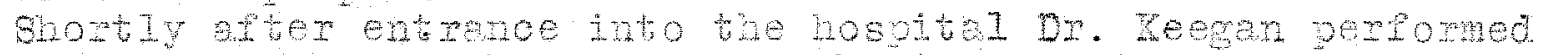

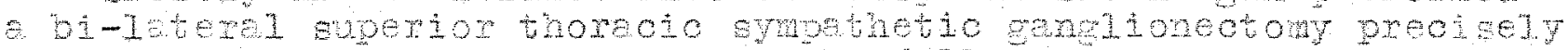

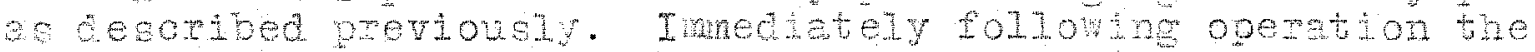
petient developec cone serious mesprotony ditiouties. Respre-

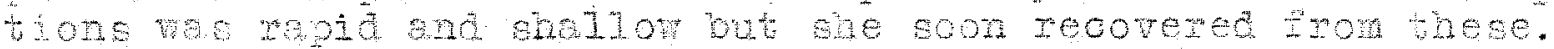

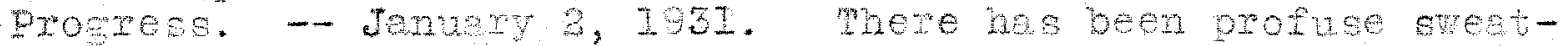
ing helow the niople line - it jo dry and vam ebove. Whe hands

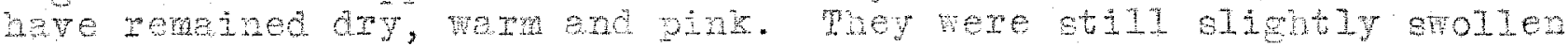

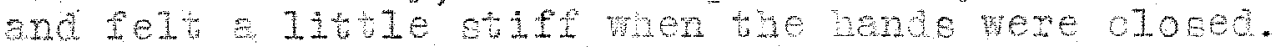




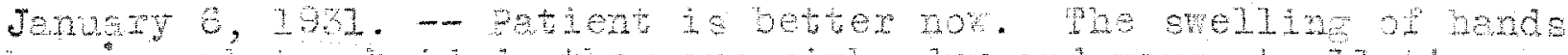

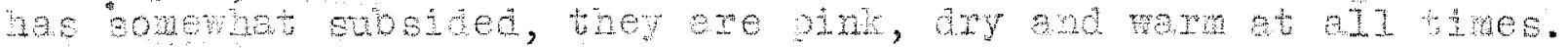

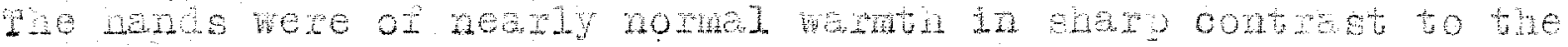
cold crenotio inet.

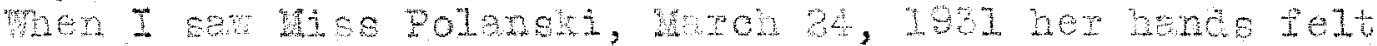

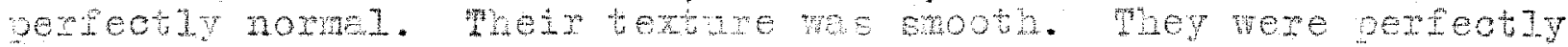

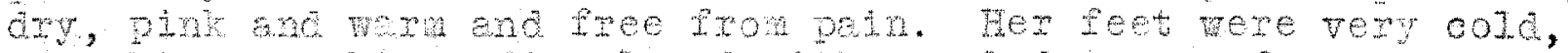
the sinn we shing, discolored with wot thed exes of deep orenoens

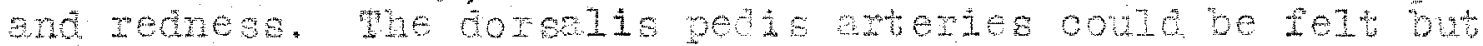

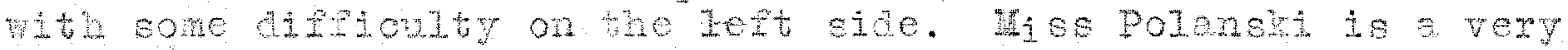
hopy wan becuse her operation hes restored her to e nomal

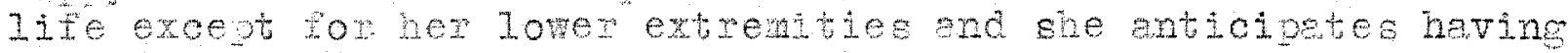
these operetsed at e. Ietex deve.

Hitsompmat'

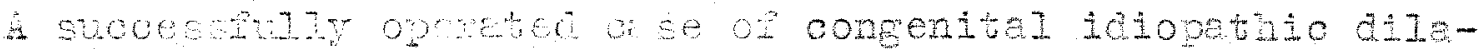
totion of the colon is the next cese to be reported.

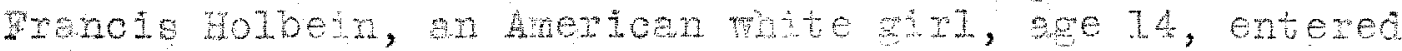

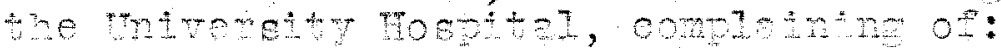

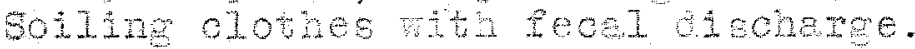

conetioetion.

onset and developrent. - whe petient ha soiled her clothes

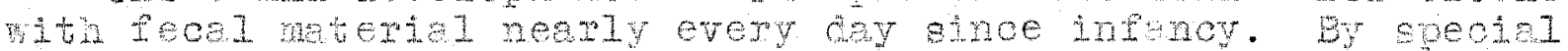
encomerement and an attent to phe the petient th was posstble to induce ner not to bota der clothes for a lew doys bue

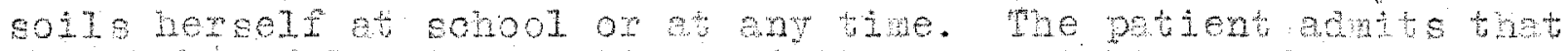

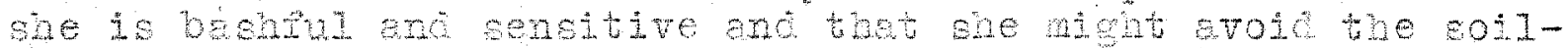

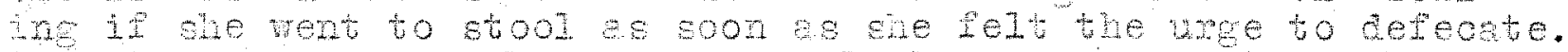
ponetipetion has not been a pertouleriy eevere complejnt but has

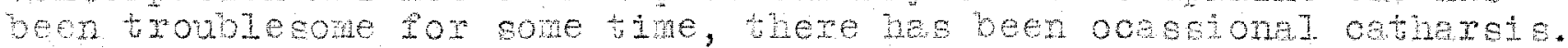

Dhyetopl exemingtion. - The petient looks heelthy herang

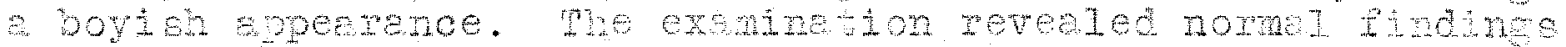

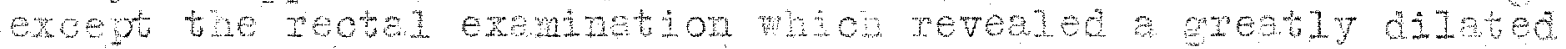
mentie.

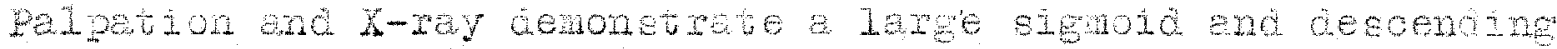
olon with evideroe of rusoular sotavity, not atony. There wes no bochanal dietention.

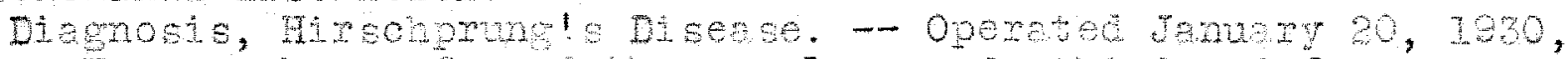

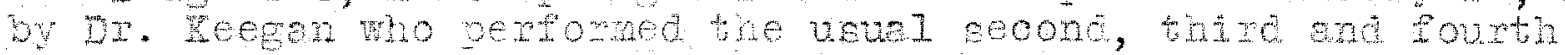
Iumber sympthetio sanelionectomy on the left side ony.

A-rey report three and a helf tontis pot operetive sare thet there is how evidenoe of havetretions in the atgnoid and decoending colon with evidence of contratibility of ne reotal ampilia.

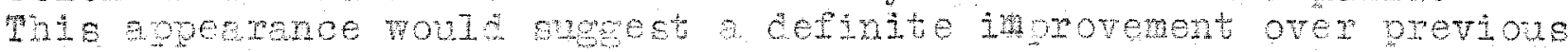
Iilm.

Check up also three and a helf monthe poet operative revente that incontinence hed ceased, conetipetion was stili troublesome

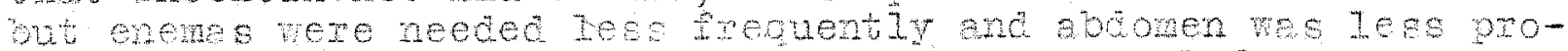

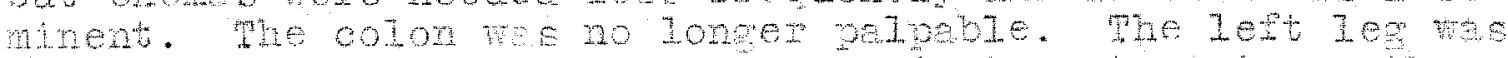

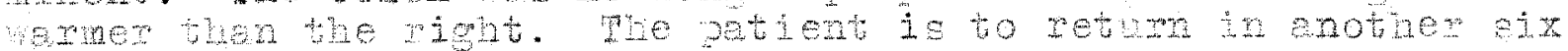
Tanthe for e check-tp.

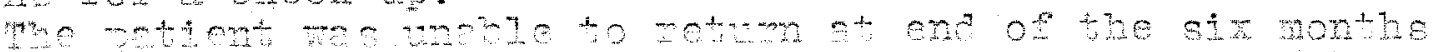

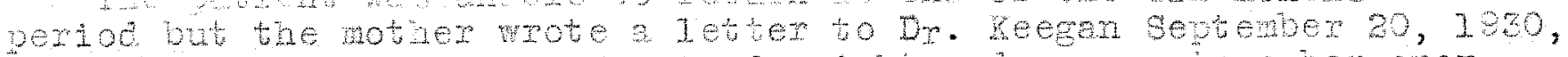

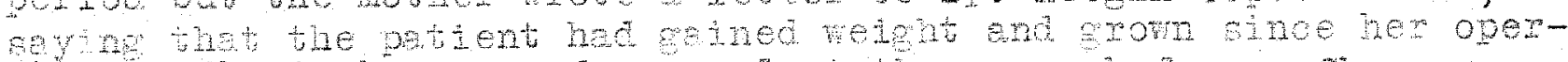
aton. She is kener and more alew then ever before. she seene 


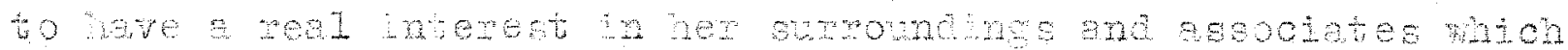

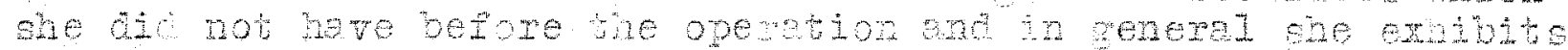

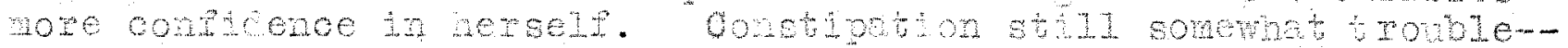
aomene et times requifes a laxative.

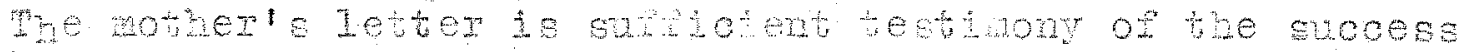

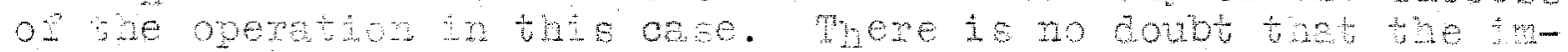
movenent wiz de permenem, and we now heve an efrective dean

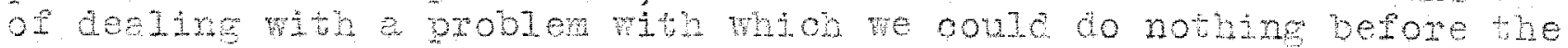
adyent of this type of surgery.

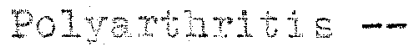

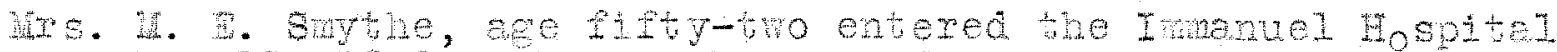

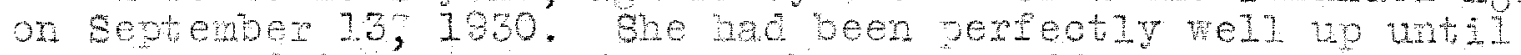

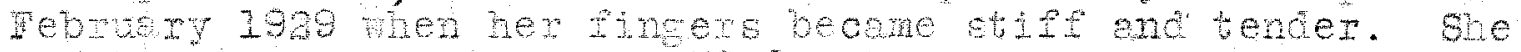
had her tonsils out in mey 1989. Wume whe sumer sho had some

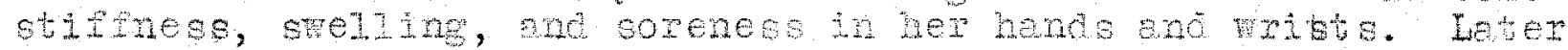

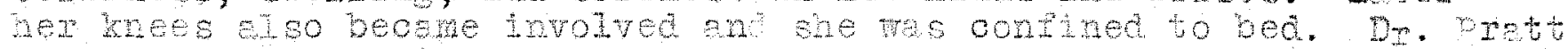

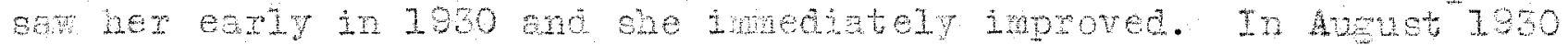
her knees begen to fet woree. At taret hey ached and wexe panful. bit now they sre lot and evollen and canot be extended. Mhysagl exenthetion.

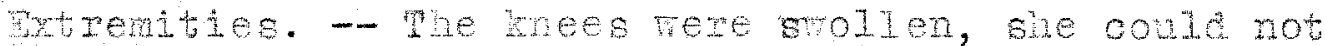

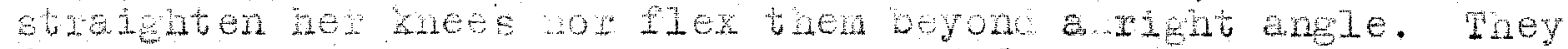
Pelt hot and tender. The hends mere depomed, the proces involv-

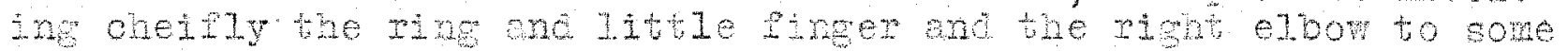
ertent.

Ditgnosis --

Probrestive stmmetrios athitis.

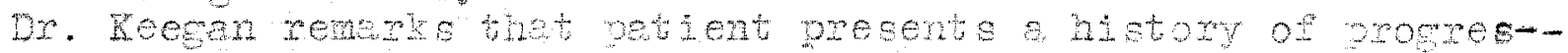

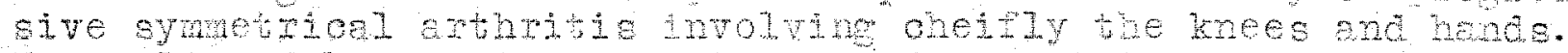
wot relieved by previoue treatrent and assoojated wh thared arestine of the bende and peet and oold extrentites. X-rey denon-

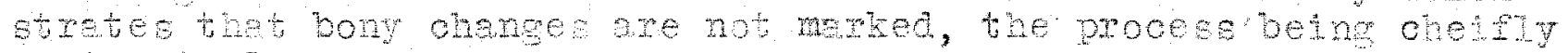
peristioular

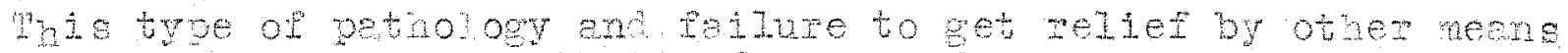

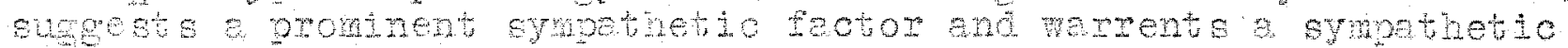
Bnglionectomy.

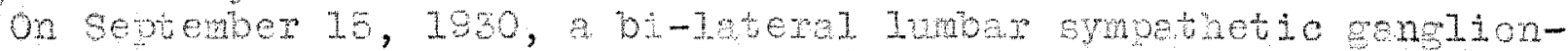
otomy we geriomed by $D_{2}$. Heesen.

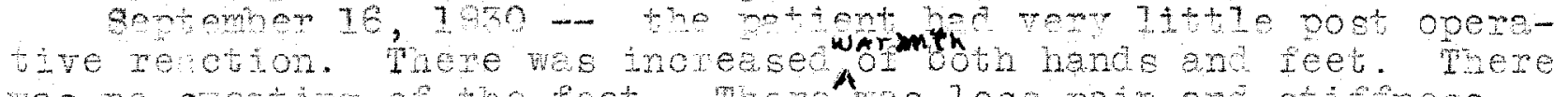
was no sweetime of the reet. merefue lese perr ane stifness th the kese whe she cond also hom her pansew better.

september 18,1930 - the patient can now llatten aer kees on the oed an more trem freely whol she ould not do berore the operetion.

Septemor 32,1930 - there is some pein and tencemese in the mees today but they can be moved ant straightened ont without much Intiotion.

september 24, 1930 - the extremities are warm end dry. There

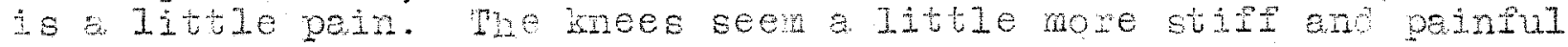
buen imediatel post operetive. 


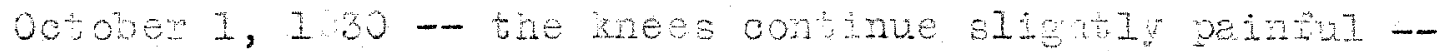

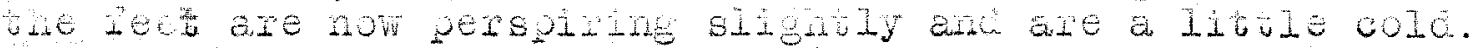

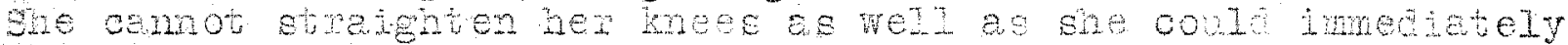
after the opretion. Whe patient states that ner feet do not

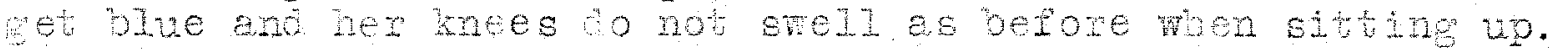
She is rethem weer and uneole to malk.

Tha cese conle rot be conejicred a complete sucoese, thomen theme he oem eone tupromenent stree operation. It is possible that all of the fibex to the lower extrentase were not out anoe thene wes still some penspination of the lese anc the renathed cold. But let it ae nemembered thet experiene tn selection of cases wiz do mon toward deoresstrg the number of fejurus.

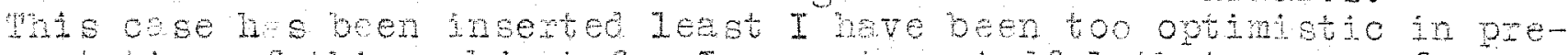
centation of this bubject for I an not minheful thet yeens of dincel expewence are reeder to mimize the erroms, whetho they be in selection ol cases on ix the operations thenseltre.

Sumaney:-

whe know tge of the symptnetic nerrous system has been inoreased by an abmcance of recent anturnicel and phystologioal researot.

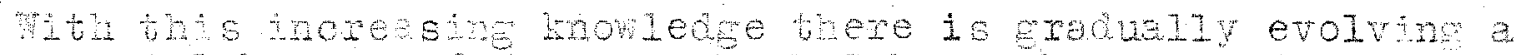
very apetal brench of eurgery which I have chosen to desibnete, surgery ot the autonomic nenvous aystr.

wo seperate procedures have been employed for tarious ooniHons:-

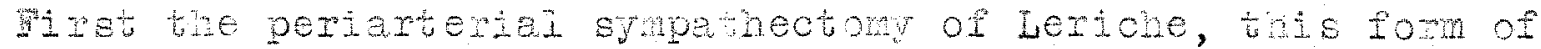
operstan I heve dispoges of wecause it does not confora to

our anetoniol en physiologied comoepts.

secono - sympethetio ganglionectony, ramisectony and trun reseotion, tha coeretion th the Itght of bhe present ay intom-

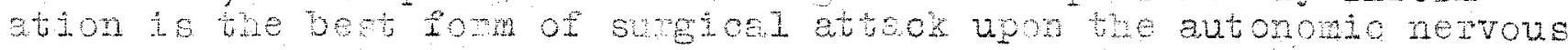
S.getsen.

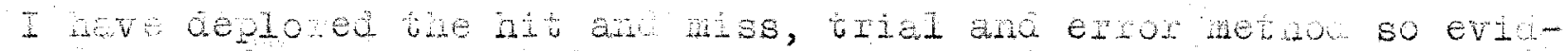

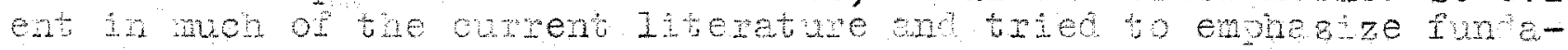

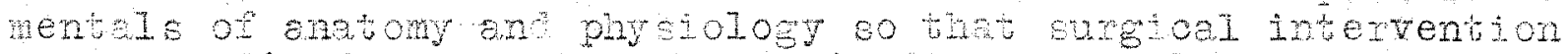

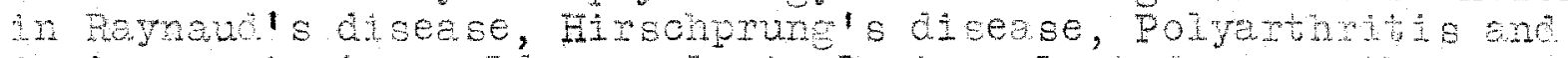

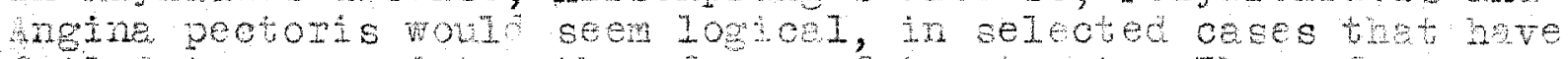
Ealles to respone to othem fomo of trestment. Whese foum con-

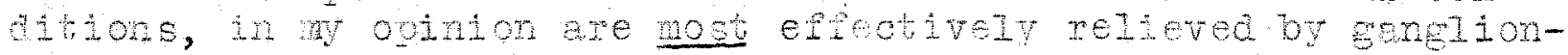
ectom.

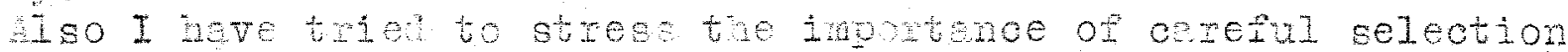
of cases fom heretr Iies not of the succes or latiure of surgery of the eutonomio nexpous system.

Whie subject should be eppoached in the true scientific spintw, witu open raned sxeptionsm and a realization thet as our whowlede of the chatom and physiology of the autonomo nervous sytren 19 incresed so with the scope of gurgery of that aystom be eniciched.

metever is scomplieded an this field te a detinct contribution th the propmese of merticino as a wole bemeves even todey

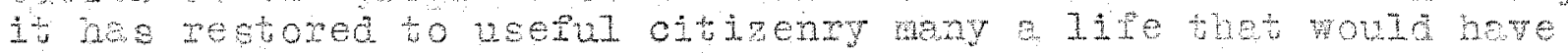
been helplese. Thithot sureery of the autonomic nervous ereten. 


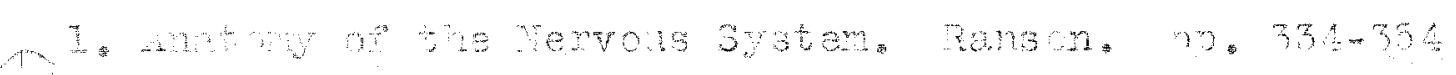

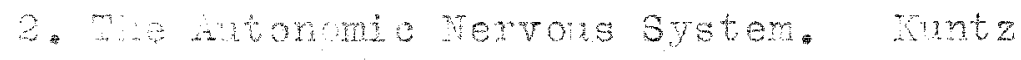

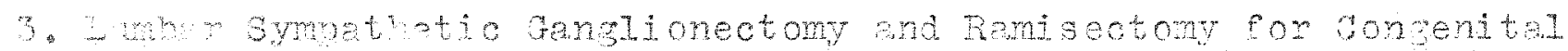

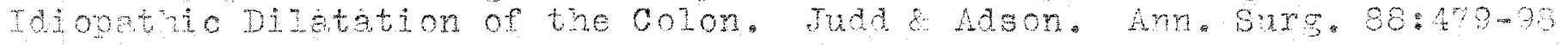

$\therefore$ araio sympthetic cardiac nerves in men.

5. Dorstolosical Gefects of mhoracic and Lunbre Sumpathetio Ganglionectony or section of the Irank.

* w thm of the Sympethetio Nervous sistem.

* Hancots Prodrod by Uni-IateraI Lum war sympthectomy. Skin pemperature

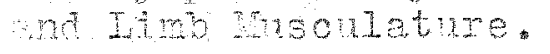

- bone protoningl Tefects of Gengioneotomy.

9. Huxr Anetomical and Physiologion Basis for Periarterial Sympethectomy.

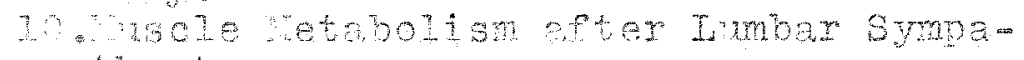
tyectory.

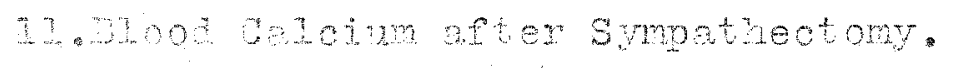

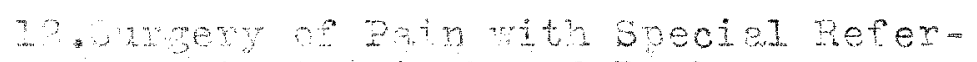
enoe to serwion and Imonr symam thectory.

23. nominental Investigation of Defeots non Logn olmoletion

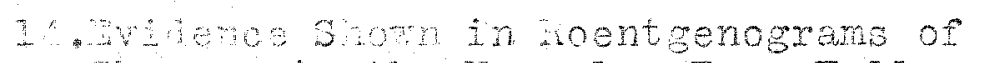
Genges in the Vasondar Tree Follow

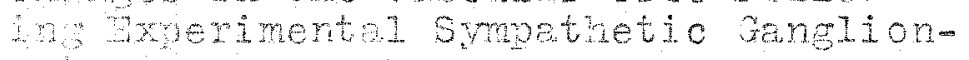
cotomin.

1. . ar arteriol sympathectomy in Girculatopt Digorders of the Lorey Dxtremity.

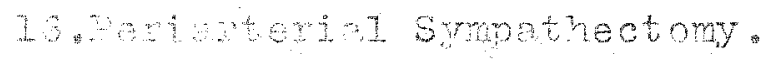

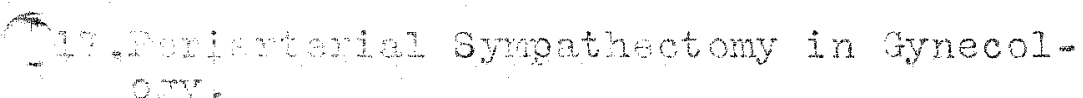
ong

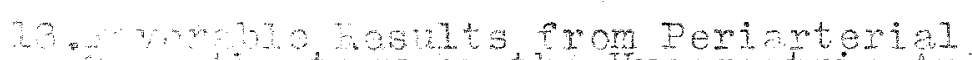
S. nutheotomy on the Myoogestyo And Grator dombies.
}
Funtz Arco. S2x-20:60\%-13 Antin 130
Brom froh. Hexrol, $92.309-5 \%$

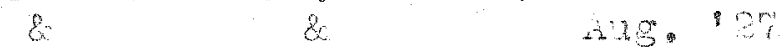 War Poychiet.
Ranson T. A.N.A. 98.2986-00 Jine $19 \cdot 26$

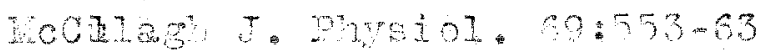 motieden? May 130 3ilroy

$$
\text { Heant Pe } 131-70
$$

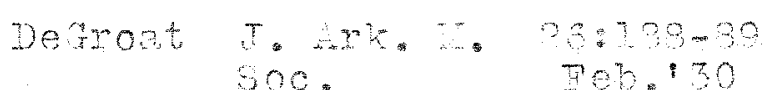

T.Pryiol. $59: 364-71$

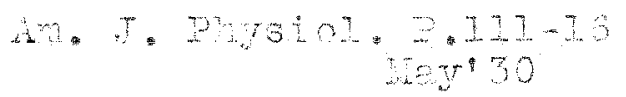

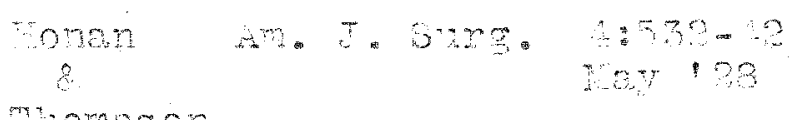

momason

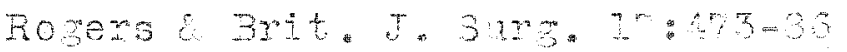

IEmingury $\quad$ Ton' 30

Sorton Exoo. Stafe keet. Wyo

8. Ginic $4: 40--4 x .150$

Craig

Benneim surs. 7tm. a onet. E. 126-20 76,130

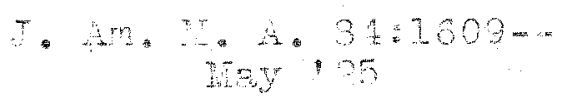

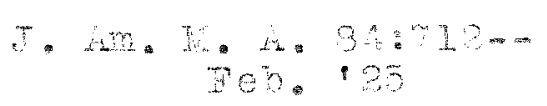

Leriche prense itedicale $33: 463 \ldots$

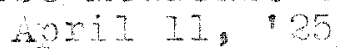


3.

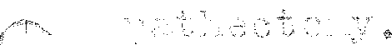

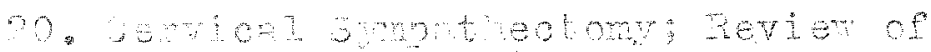

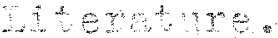

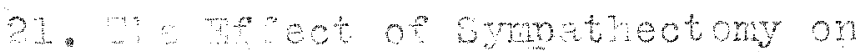
spatic Pandyeis of the mutrenttis.

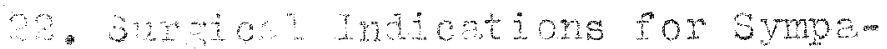
Wetio Ganglionectomy and Trunk sesection in Ireetment of Diserses resuling from Vasospasm of Periphard reteras.

23. Diamostio 310 ong of Symothetic J.o. Wite Uerres to the Txtremities with Prooane.

21. 2ystological stidies in Vasomotor ater Lumba sumethetio Genalionectory and Perivasoular Heurotony.

5. mane peotois: nelief or Pan by o. Thto Jeratertebral Aloohol Block of Uper tomel bymothetio Rami.

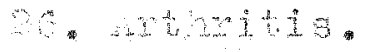
Eemberton

an. Preatmont of Arthitis Deformens of the Xxtremities.

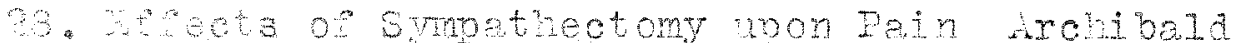
of orenio Disense of Arteries of the lower Lim and for Obscrue Abdomm Inei Feino

29. Derinteriaz Merves.

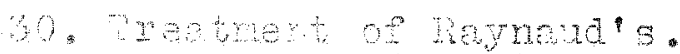

A.son

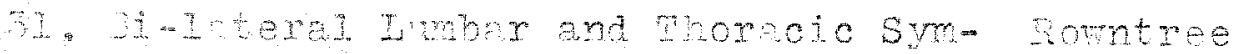
ntmatto Gnglinneotomy nd Rami$c$ sotmy sor Polyerthritis of the TX-Adson Himities.

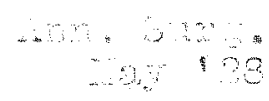

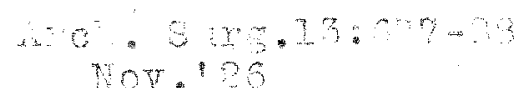

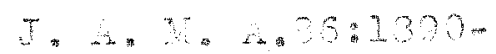

93

The $12: 06$

$3 x] \cdot T \cdot Y * 406 \%$

$\operatorname{red}, 5 \cdot 17-32$

J.A.M.A. $94: 1382-88$ MAY, 3, 1930 .

an, Gin, Red. $5: 168-75$

$428 \cdot 26$

woh Metrol de prow. $20.302-129$

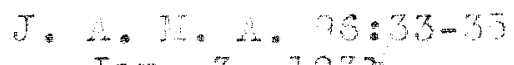
$\operatorname{Jan}, 3,1931$

Ken. I. J. 23:130-60 $12 \times 2 * 30$

m. Am. S.4. 46: 199

1928

J.A. M. A. $34: 1453=$

burs. Gyn. 2. Obst. $48: 57-129$

Mr. A, Am, Phye, Vol.4u P. $221-230$

1929. 